\title{
Degassing dynamics of basaltic lava lake at a top-ranking volatile emitter: Ambrym volcano, Vanuatu arc
}

DOI:

10.1016/j.epsl.2016.05.014

\section{Document Version}

Accepted author manuscript

Link to publication record in Manchester Research Explorer

\section{Citation for published version (APA):}

Allard, P., Burton, M., Sawyer, G., \& Bani, P. (2016). Degassing dynamics of basaltic lava lake at a top-ranking volatile emitter: Ambrym volcano, Vanuatu arc. Earth and Planetary Science Letters, 448, 69-80.

https://doi.org/10.1016/j.epsl.2016.05.014

\section{Published in:}

Earth and Planetary Science Letters

\section{Citing this paper}

Please note that where the full-text provided on Manchester Research Explorer is the Author Accepted Manuscript or Proof version this may differ from the final Published version. If citing, it is advised that you check and use the publisher's definitive version.

\section{General rights}

Copyright and moral rights for the publications made accessible in the Research Explorer are retained by the authors and/or other copyright owners and it is a condition of accessing publications that users recognise and abide by the legal requirements associated with these rights.

\section{Takedown policy}

If you believe that this document breaches copyright please refer to the University of Manchester's Takedown Procedures [http://man.ac.uk/04Y6Bo] or contact uml.scholarlycommunications@manchester.ac.uk providing relevant details, so we can investigate your claim.

\section{OPEN ACCESS}




\title{
Degassing dynamics of basaltic lava lake at a top-ranking volatile emitter: Ambrym volcano, Vanuatu arc
}

\author{
Patrick Allard ${ }^{1,2^{*}}$, Mike Burton ${ }^{3}$, Georgina Sawyer ${ }^{4}$ and Philipson Bani ${ }^{5}$ \\ ${ }^{1}$ Institut de Physique du Globe de Paris, UMR7154 CNRS, Paris, France \\ ${ }^{2}$ Istituto Nazionale di Geofisica e Vulcanologia, Catania, Italy \\ ${ }^{3}$ SEAES, University of Manchester, United Kingdom \\ ${ }^{4}$ Department of Geography, University of Cambridge, United Kingdom \\ ${ }^{5}$ IRD, Laboratoire Magmas \& Volcans, Clermont-Ferrand, France \\ * Corresponding author (E-mail: pallard@ipgp.fr) \\ Institut de Physique du Globe de Paris (IPGP), 1 rue Jussieu, 75005 Paris, France
}

\begin{abstract}
$\underline{\text { Abstract }}$
Persistent lava lakes are rare on Earth and provide volcanologists with a remarkable opportunity to directly investigate magma dynamics and degassing at the open air. Ambrym volcano, in Vanuatu, is one of the very few basaltic arc volcanoes displaying such an activity and voluminous gas emission, but whose study has long remained hampered by challenging accessibility. Here we report the first high temporal resolution (every $5 \mathrm{sec}$ ) measurements of vigorous lava lake degassing inside its $300 \mathrm{~m}$ deep Benbow crater using OP-FTIR spectroscopy. Our results reveal a highly dynamic degassing pattern involving (i) recurrent (100-200 sec) short-period oscillations of the volcanic gas composition and temperature, correlating with pulsated gas emission and sourced in the upper part of the lava lake, (ii) a continuous long period ( $\sim 8 \mathrm{~min})$ modulation probably due to the influx of fresh magma at the bottom of the lake, and (iii) discrete $\mathrm{CO}_{2}$ spike events occurring in coincidence with the sequential bursting of meter-sized bubbles, which indicates the separate ascent of large gas bubbles or slugs in a feeder conduit with estimated diameter of $6 \pm 1 \mathrm{~m}$. This complex degassing pattern, measured with unprecedented detail and involving both coupled and
\end{abstract}


decoupled magma-gas ascent over short time scales, markedly differs from that of quieter lava lakes at Erebus and Kilauea. It can be accounted for by a modest size of Benbow lava lake and its very high basalt supply rate $\left(\sim 20 \mathrm{~m}^{3} \mathrm{~s}^{-1}\right)$, favouring its rapid overturn and renewal. We verify a typical basaltic arc signature for Ambrym volcanic gas and, based on contemporaneous $\mathrm{SO}_{2}$ flux measurements, we evaluate huge emission rates of $160 \mathrm{Gg} \mathrm{d}^{-1}$ of $\mathrm{H}_{2} \mathrm{O}, \sim 10 \mathrm{Gg} \mathrm{d}^{-1}$ of $\mathrm{CO}_{2}$ and $\sim 8 \mathrm{Gg} \mathrm{d}^{-1}$ of total acid gas $\left(\mathrm{SO}_{2}, \mathrm{HCl}\right.$ and $\left.\mathrm{HF}\right)$ during medium activity of the volcano in 2008. Such rates make Ambrym one of the three most powerful volcanic gas emitters at global scale, whose atmospheric impact at local and regional scale may be considerable.

Keywords:

Ambrym, lava lake, infrared spectroscopy, volcanic gases, magma degassing dynamics, volatile fluxes 


\section{Highlights}

- $\quad$ First OP-FTIR spectroscopic measurement of vigorously degassing lava lake on Ambrym arc volcano

- $\quad$ Highly dynamic degassing pattern with both short- and long-period modulations, plus discrete $\mathrm{CO}_{2}$-rich events

- Magma degassing dynamics markedly differs from that for quieter lava lakes at Kilauea and Erebus

- Chemical characterization of high-temperature basaltic gases from an intra-oceanic island arc

- Quantification of gas fluxes from a top-ranking emitter of volcanic volatiles worldwide 


\section{Introduction}

2

Persistent lava lake activity, occurring at rare volcanoes worldwide, is a remarkable phenomenon where molten magma steadily supplied to an open reservoir degasses directly into the atmosphere from across its surface, while loosing little to no solid mass (e.g. Le

6 Guern et al., 1979; Tazieff, 1994; Oppenheimer et al., 2004, 2009). Such an activity, which can persist for decades (e.g. at Kilauea and Erebus volcanoes) to more than a century (Nyiragongo and Erta'Ale volcanoes), is of great value in volcanological research as it exposes what is normally hidden within persistently active volcanoes: the innermost magma dynamics capable to sustain continuous gas and heat flow. Its study therefore permits direct comparison between measured geophysical and geochemical parameters and volcanic activity, allowing features such as magma convection, passive degassing, lava fountains or explosive gas bubbling to be understood in a quantitative framework.

Because degassing contributes most of the total mass output from a lava lake, key insights into the processes controlling this rare volcanic activity can be obtained by measuring the chemistry and flux of magmatic gas emissions. Gas fluxes provide quantitative constraints on the rates of magma supply and convection, while gas compositions provide constraints upon the degassing mechanisms and their source depth if the abundance and behaviour of volatiles in the magma are known (e.g. Allard et al., 2005; Oppenheimer et al., 2009; Beckett et al., 2014). Efficient convective magma overturn in lava lake-conduit systems, with gravitational sinking of the unerupted degassed magma, is strongly required from heat and mass balances (e.g. Tazieff, 1994; Kazahaya et al., 1994; Stevenson and Blake, 1998; Harris et al., 1999; Oppenheimer et al., 2004, 2009; Beckett et al., 2014). It is also supported by theoretical modelling (Witham and Llewellin, 2006) and cyclic crystal zonation in erupted solid products 
heat and gas to a lava lake (Bouche et al., 2013) and to control its level oscillations through bubble accumulation at its top (Patrick et al., 2016). Variations in magma-gas supply rates, degassing modes and the style of convection actually determine a wide range in lava lake behaviour, from vigorous bubbling and overturn to quieter degassing and resurfacing, interrupted or not by recurrent gas outbursts (e.g. Le Guern et al., 1979; Tazieff, 1994; Oppenheimer et al., 2004, 2009), and to cyclic upheaval and drain back due to gas-piston effects (Edmonds and Gerlach, 2007; Patrick et al., 2016).

The composition and mass output of magmatic gases from a lava lake can be measured using up-to-date spectroscopic methods. In the past fifteen years, open-path Fourier transform infrared (OP-FTIR) spectroscopy has been demonstrated to be a remarkable tool for remotely quantifying magmatic gas compositions during effusive and explosive eruptions at high frequency and from a safe position (e.g. Allard et al., 2005; Burton et al., 2007a; La Spina et al., 2015). Using infrared radiation emitted by molten lava, OP-FTIR absorption spectroscopy allows simultaneous determination of the principal components of hot volcanic gases: $\mathrm{H}_{2} \mathrm{O}$, $\mathrm{CO}_{2}, \mathrm{SO}_{2}, \mathrm{HCl}, \mathrm{HF}, \mathrm{CO}$, apart from $\mathrm{H}_{2}$ and $\mathrm{H}_{2} \mathrm{~S}$. Therefore, this tool is particularly wellsuited to study the degassing of lava lakes. It has already been applied to study gas emissions from the exceptional long-lived lava lakes hosted by Nyiragongo on the East-African Rift (Sawyer et al., 2008a), Erta'Ale in Ethiopia (Sawyer et al., 2008b), Erebus in Antarctica (Oppenheimer and Kyle, 2008; Oppenheimer et al., 2009; Ilanka et al., 2015) and Kilauea in Hawaii (Edmonds and Gerlach, 2007; Edmonds et al., 2013; Patrick et al., 2016). These four volcanoes, located on either hot spots or rift zones, are fueled by magmas ranging in composition from basalt (Kilauea, Erta'Ale) to nephelinite (Nyiragongo) and phonolite (Erebus), which is reflected in widely differing gas compositions. OP-FTIR spectroscopy has also been applied on two of the rare basaltic to andesitic volcanoes in subduction zones where lava lakes have been observed to recurrently form and persist: Masaya in Nicaragua (Burton 
et al., 2000) and Villarrica in Chile (Sawyer et al., 2011). However, until now comprehensive OP-FTIR investigation of the degassing dynamics of a lava lake has been achieved only on Erebus (Oppenheimer et al., 2009; Ilanka et al., 2015) and Kilauea (Edmonds and Gerlach, 2007; Edmonds et al., 2013; Patrick et al., 2016), where long or detailed enough series of measurements could be realized.

Here we report on the first OP-FTIR study of the dynamics of lava lake degassing at Ambrym, in Vanuatu, a remarkable basaltic arc volcano displaying such an activity and intense gas emissions in the southwest Pacific region. Ambrym island, located in the central part of Vanuatu arc (Fig. 1a), is the subaerial exposure of a massive $\left(\sim 500 \mathrm{~km}^{3}\right)$ basaltic shield volcano rising $1800 \mathrm{~m}$ above the sea floor. At its summit, a $12-\mathrm{km}$ wide caldera which formed about 2 ka ago (MacCall et al., 1970) hosts two large active cones, Benbow and Marum (Fig. 1b), where the degassing of recurrent lava lakes sustains voluminous gas release. Because of the remote location of the volcano, challenging access to its vents and adverse tropical weather conditions, this activity has long remained unstudied. The very first airborne and ground-based measurements, performed in 2005-2007, revealed prodigious gas emission rates from Ambrym (Bani et al., 2009, 2012; Allard et al., 2015), ranking it amongst the strongest persistent emitters of volcanic volatiles on Earth (Allard et al., 2015). However, no high temporal resolution data were collected in these studies.

In October 2008 we therefore conducted OP-FTIR spectroscopic measurements on Ambrym in order to measure the dynamics of its lava lake activity at high temporal resolution. Our measurements were made from the shortest possible distance to the lava lake that was actively degassing for $\sim 1.5$ years at the bottom of its $\sim 300 \mathrm{~m}$ deep Benbow vent, and volcanic gas composition was retrieved every $5 \mathrm{sec}$. While providing new constraints on Ambrym gas chemistry, our results reveal short-term oscillations in volcanic gas composition, 
Morlet wavelet analysis of these compositional variations is combined with our field observations and melt inclusion data for dissolved volatiles (Allard et al., 2015) to infer the magmatic processes controlling this degassing pattern. Moreover, by combining our OP-FTIR data set with the $\mathrm{SO}_{2}$ plume flux determined from contemporaneous airborne UV sensing we quantify the gas emission rates. The results, discussed in comparison with data for other lava lakes in different geodynamic contexts, confirm Ambrym volcano's status as one of the three most powerful persistent emitters of magmatic volatiles on Earth. Hence, our study provides new information on the high frequency dynamics of lava lake degassing at a top-ranking arc emitter of basaltic gases, and further insights into magma dynamics at basaltic volcanoes in general.

\section{Volcanic activity and methodology}

Our measurements, on 5 October 2008, targeted the active lava lake that was vigorously degassing at the bottom of Ambrym's Benbow cone (1160 m elevation a.s.1. and $\sim 300 \mathrm{~m}$ deep). In order to determine magmatic gas compositions with OP-FTIR spectroscopy, we climbed down the eastern inner wall of the cone with our equipment (Fig. 1c) then climbed across the eastern edge of the crater terrace before reaching the northern pit crater $(815 \mathrm{~m}$ a.s.l.) hosting the lake. It is the first time OP-FTIR spectroscopy was operated so deeply inside a volcanic vent. The lava lake was ponding at $\sim 110 \mathrm{~m}$ depth in the southern part of the pit, a few meters lower than the crater floor (Figs. 1d), as measured with laser range-finding binoculars. It was approximately circular, with a diameter of $\sim 25 \mathrm{~m}$, but possibly extended more widely under the crater floor (Fig. 2). Even though concentrated gas fumes sometimes obscured its viewing, we could observe that the overall lava lake surface was repeatedly turned over by vigorous spattering, associated with a pulsated degassing (puffs), and, 
intermittently, by the sequential bursting of very large (meter-sized) gas bubbles. Otherwise, its level remained broadly stable during our measurements.

We positioned our spectrometer, its controlling laptop and a $12 \mathrm{~V} \mathrm{DC}$ powering battery on

104 the northern rim of the pit $\left(16^{\circ} 15.312 \mathrm{~S}\right.$ and $\left.168^{\circ} 06.240 \mathrm{E}\right)$, outside the volcanic gas plume.

105 The spectrometer, occasionally realigned to optimize viewing around a mobile dense gas 106 plume, targeted the center of the lava lake at an average slanting distance of $140 \pm 10 \mathrm{~m}$ (Fig.

107 2). Its $20 \mathrm{mrad}$ field of view allowed us to measure infrared radiation emitted by a $\sim 7 \pm \mathrm{m}^{2}$ 108 lake area. Our spectrometer was a MIDAC 4401-S equipped with a ZnSe beam splitter and a 109 Stirling engine cooled MCT detector (avoiding the logistically challenging need of liquid 110 nitrogen). The detector has a 600 to $5000 \mathrm{~cm}^{-1}$ sensitivity and $0.5 \mathrm{~cm}^{-1}$ resolution. Single-

111 sided interferograms of the IR radiation emitted by molten lava and absorbed by atmospheric 112 and volcanic gases were collected at a frequency of $1 \mathrm{~Hz}$ over a period of 1.6 hours (except 113 for a $20 \mathrm{~min}$ interruption due to rainfall). To improve the signal-to-noise ratio and hence the 114 quality of recorded spectra, five consecutive interferograms were co-added and subsequently 115 Fourier transformed by applying power spectrum phase correction and Norton-Beer medium 116 apodization. We thus obtained 943 FTIR spectra of Benbow lava lake degassing at 5 sec 117 period.

118 Spectroscopic gas features were in absorption, indicating a lower temperature of the 119 measured gas compared to the radiating source. They were analyzed following the retrieval 120 procedures developed for OP-FTIR spectrum analysis (Burton et al., 2000), refined for higher 121 temperature gases (Allard et al., 2005; La Spina et al., 2015). For each spectrum we retrieved 122 the column amounts (expressed in units of molecules. $\mathrm{cm}^{-2}$ ) of eight IR-active gas species in 123 the following wave bands: $\mathrm{H}_{2} \mathrm{O}$ and $\mathrm{CO}_{2}\left(2040-2165 \mathrm{~cm}^{-1}\right), \mathrm{SO}_{2}\left(2490-2550 \mathrm{~cm}^{-1}\right), \mathrm{HCl}$ and $124 \mathrm{CH}_{4}\left(2690-2810 \mathrm{~cm}^{-1}\right)$, HF $\left(4035-4210 \mathrm{~cm}^{-1}\right)$, $\mathrm{CO}$ and $\mathrm{N}_{2} \mathrm{O}\left(2145-2245 \mathrm{~cm}^{-1}\right)$. Gas column 125 amounts were obtained from nonlinear least-squares best fitting (Rodgers 1976's optimal 
126 estimation algorithm) between the measured spectra and simulated spectra based on the 127 radiative transfer forward model of Edwards and Dudhia (1996) and infrared absorption line 128 parameters from the HITRAN database (Rothman et al., 2005). The standard deviation of 129 fitting residuals across the respective spectral windows yields an estimate of the error on the 130 retrieved column amount of each gas, illustrated by error bars in the plots of Figure 3.

131 Radiative transfer in the two layers of hot volcanic gas and ambient atmospheric gases viewed 132 by the spectrometer was calculated using the temperature of each layer. For the atmospheric 133 layer we used the ambient temperature $\left(292.6^{\circ} \mathrm{K}\right)$ and pressure $(919 \mathrm{hPa})$ measured on site 134 with a hand-held meteorological sensor. The temperature of the volcanic gas layer was 135 determined for each spectrum from the highly $\mathrm{T}$-dependent rotational band structure of $\mathrm{SO}_{2}$ at $1362500 \mathrm{~cm}^{-1}$ (Allard et al., 2005; Burton et al., 2007a). We also determined the temperature of 137 the radiating source from the ratio of IR intensity recorded at 4400 and $4460 \mathrm{~cm}^{-1}$ and by 138 fitting to a scaled Planck curve (Allard et al., 2005).

139 Our data time series for the volcanic gas amounts and gas ratios are depicted in Figures 4 140 and 5. In order to identify and quantify possible degassing periodicities, we performed a 141 continuous Morlet wavelet transform (CMWT) analysis of the gas ratios time series, using the 142 code of Grinsted et al. (2004). CMWT analysis is particularly suitable for studying natural 143 processes not stationary in time (Torrence and Combo, 1998), such as volcanic degassing 144 (e.g. Tamburello et al., 2013; Ilanko et al., 2015); it permits to examine periodicities of a time 145 series by moving and stretching a Morlet guide-wave and analyzing step-by-step its 146 correlation with the signal. Wavelet power spectra reveal the strength of periodicities at 147 different times and for different periods. Our data time series for Ambrym were close to 148 normal distribution and thus did not require prior log-transformation. They were simply 149 resampled at $1 \mathrm{~Hz}$ in order to get a time series with uniform step from 0 to 2885 seconds. The 150 code of Grinsted et al. (2004) was used with the default parameters (e.g. automatic estimation 
151 of the background power spectrum, 1/12 octaves per scale) and result significance was 152 assessed by assuming a red noise background, automatically modeled by a first order 153 autoregressive (AR1) estimator. The code adds a cone of influence (COI) in which edge 154 effects related to the length of the time series cannot be ignored. In our study this prevented 155 from detecting periodicities lower than 6 seconds. We also checked the phase relationship 156 between selected pairs of gas ratios by computing the coherence spectra between their wavelet 157 transforms (Torrence and Combo, 1998). Results are displayed in Figures 6 and 7 and 158 discussed in section 4.2.

159 Finally, during our field campaign, on October 8, the bulk $\mathrm{SO}_{2}$ plume flux from Ambrym

160 and the respective flux contribution from Benbow and Marum craters were determined using 161 airborne UV (DOAS) absorption spectroscopy. The results are reported in Allard et al. (2015).

162 Combining these data with our OP-FTIR results therefore allows us to quantify both the 163 single and total gas emission rates from Benbow crater and Ambrym in October 2008.

164

\section{Results}

\subsection{Gas temperature and column amounts}

The temperature of air-diluted Benbow volcanic gas was found to vary between 300 and $420^{\circ} \mathrm{K}$, with a mean of $340 \pm 20^{\circ} \mathrm{K}$. Such low temperatures, compared to $\sim 1400^{\circ} \mathrm{K}$ at emission

170 from the molten basalt (section 4.2), demonstrate a rapid cooling of the magmatic gas upon 171 emission and dilution by entrained ambient air. A higher mean temperature of $770 \pm 120^{\circ} \mathrm{K}$ 172 was determined for the radiating source, consistent with all spectra being in absorption. The 173 mean thermal contrast of $330^{\circ} \mathrm{K}$ between the IR source and the volcanic gas warrants a 174 negligible contribution of thermal emission from hot gases themselves in the spectral region 175 of interest $\left(>2000 \mathrm{~cm}^{-1}\right)$. 
As previously mentioned, eight IR-active gas species $\left(\mathrm{H}_{2} \mathrm{O}, \mathrm{CO}_{2}, \mathrm{SO}_{2}, \mathrm{HCl}, \mathrm{HF}, \mathrm{CO}, \mathrm{CH}_{4}\right.$ and $\mathrm{N}_{2} \mathrm{O}$ ) were retrieved in our spectra. The overall uncertainty on their amounts due to measurement and retrieval ranges between 4 and $7 \%$ for $\mathrm{SO}_{2}, \mathrm{HCl}$, and $\mathrm{HF}, 8-10 \%$ for $\mathrm{H}_{2} \mathrm{O}$, $\mathrm{CO}_{2}$ and $\mathrm{N}_{2} \mathrm{O}$, and $10-12 \%$ for $\mathrm{CO} . \mathrm{CH}_{4}$, absent in hot basaltic gases and affected by a greater uncertainty, is left out in the following. Whilst $\mathrm{SO}_{2}, \mathrm{HCl}$ and $\mathrm{HF}$ are purely volcanic in origin, $\mathrm{H}_{2} \mathrm{O}, \mathrm{CO}_{2}$ and $\mathrm{CO}$ are both volcanic and atmospheric components, so their amounts must be corrected for air dilution. $\mathrm{N}_{2} \mathrm{O}$, which is purely atmospheric, is a reliable indicator for that correction. For the abundance of $\mathrm{N}_{2} \mathrm{O}(0.32 \mathrm{ppmv})$ and other gases in Vanuatu's atmosphere in October 2008 we refer to the data recorded by the CSIRO air monitoring station of Cap Ferguson (http://www.csiro.au/greenhouse-gases/), eastern Australia, which is the closest station of the World Meteorological Organization (Fig. 1a).

Figure 3 shows scatter plots of the bulk path amounts of (a) $\mathrm{SO}_{2}$ versus $\mathrm{HCl}$, (b) $\mathrm{HCl}$ versus $\mathrm{HF}$, (c) $\mathrm{CO}_{2}$ versus $\mathrm{SO}_{2}$ and (d) $\mathrm{H}_{2} \mathrm{O}$ versus $\mathrm{HCl}$ in our 943 spectra. In each plot the gradient of linear regression defines the average molar ratio of the species in the pure volcanic gas. The values are $3.1 \pm 0.4$ for $\mathrm{SO}_{2} / \mathrm{HCl}, 1.9 \pm 0.3$ for $\mathrm{HCl} / \mathrm{HF}, 2.0 \pm 1.4$ for $\mathrm{CO}_{2} / \mathrm{SO}_{2}$, and $560 \pm 140$ for $\mathrm{H}_{2} \mathrm{O} / \mathrm{HCl}$. Besides analytical uncertainties, the standard deviation on these ratios includes temporal fluctuations in the volcanic gas composition, as described thereafter. In Figures $3 \mathrm{c}$ and $3 \mathrm{~d}$, the offset on the $y$-axis characterizes the respective air background amount of $\mathrm{CO}_{2}\left(1.55 \times 10^{20}\right.$ molecules.cm $\left.{ }^{-2}\right)$ and $\mathrm{H}_{2} \mathrm{O}\left(6.5 \times 10^{21}\right.$ molecules.cm $\left.{ }^{-2}\right)$ in the pit crater in the absence of any volcanic gas. The variable proportion (from $3 \%$ to $24 \%$ ) of admixed volcanic gas implies significant temporal changes in the thickness of the measured volcanic layer. This

197 is verified by computing the optical thickness of the purely atmospheric gas layer from the amount of $\mathrm{N}_{2} \mathrm{O}$ in each spectrum: $\mathrm{L}_{\mathrm{a}}=\left(\mathrm{N}_{\mathrm{N} 2 \mathrm{O}}\right) \cdot \mathrm{T}_{\mathrm{a}} /\left(7 \cdot 243 \times 10^{14} \cdot \mathrm{P}_{\mathrm{a}} \cdot\left[\mathrm{N}_{2} \mathrm{O}\right]_{\mathrm{a}}\right)$, where $\left[\mathrm{N}_{2} \mathrm{O}\right]_{\mathrm{a}}=0.32$

199 ppmv and $\mathrm{T}_{\mathrm{a}}$ and $\mathrm{P}_{\mathrm{a}}$ are the ambient temperature and pressure. The average $\mathrm{N}_{2} \mathrm{O}$ amount in all 200 spectra, $(9.5 \pm 0.7) \times 10^{16}$ molecules. $\mathrm{cm}^{-2}$, constrains a mean atmospheric path length of $130 \pm 10$ 
$\mathrm{m}$, somewhat lower than our measuring distance to the center of the lake $(140 \pm 10 \mathrm{~m})$, suggesting a mean thickness of order $10 \mathrm{~m}$ for the volcanic gas layer. However, the range in single air path values, from 100 to $160 \mathrm{~m}$, demonstrates important fluctuations of the volcanic layer, in agreement with the pulsated degassing of the lava lake. The longest atmospheric paths, corresponding to low volcanic gas amounts, approach the slanting distance $(170 \mathrm{~m})$ between our measuring site and the southern wall of the pit behind the lava lake (Fig. 2); they thus indicate a thinned volcanic layer during transient episodes of reduced lake degassing. Instead, the shortest air paths correlate with both a higher gas temperature and a greater amount of total volcanic gas (a rough proxy for the gas flux), indicating a thicker volcanic 210 layer and more intense lake degassing. On a few occasions, however, a thicker volcanic layer 211 was an artefact due to backward turbulent transport of the volcanic gas cloud that, in addition 212 to the targeted hot gases, was seen to cross the field of view of our spectrometer.

213 By subtracting the atmospheric background amounts discussed above, we thus obtain the 214 air-corrected volcanic amounts of $\mathrm{CO}_{2}$ and $\mathrm{H}_{2} \mathrm{O}$. For a finer air correction on much less 215 abundant carbon monoxide, we combined the atmospheric path value derived from $\mathrm{N}_{2} \mathrm{O}$ in 216 each spectrum with Vanuatu's atmospheric CO content $(0.07 \mathrm{ppmv})$ in October 2008. Figure 2174 depicts the time series of purely volcanic $\mathrm{H}_{2} \mathrm{O}, \mathrm{CO}_{2}, \mathrm{SO}_{2}, \mathrm{HCl}, \mathrm{HF}$ and $\mathrm{CO}$, as well as of the 218 volcanic gas temperature and of the $\mathrm{N}_{2} \mathrm{O}$-based atmospheric path length. As expected, the 219 temperature and the column amounts of volcanic gases display significant co-variations that 220 are anti-correlated with changes in the atmospheric path length: the shorter the latter, the 221 higher the former, and reciprocally.

\subsection{Temporal variations in gas ratios}

224 In contrast to gas column amounts, the volcanic gas ratios are insensitive to variable air 225 dilution and thus track purely volcanic processes. Now, our data set reveals significant short- 
226 term fluctuations of the gas ratios (Figs. 5a-c) and hence of the bulk volcanic gas 227 composition, which are well beyond the errors in our spectral retrievals. These variations 228 reveal a highly dynamic degassing pattern of Benbow lava lake, as verified by the Morlet 229 wavelet analysis of our data time series. Figure 6 shows the wavelet periodograms for 230 temperature and five selected gas ratios, while Figure 7 depicts the wavelet coherence and 231 phase relationship between (a) $\mathrm{SO}_{2} / \mathrm{HF}$ and $\mathrm{HCl} / \mathrm{HF}$ and (b) $\mathrm{CO}_{2} / \mathrm{SO}_{2}$ and $\mathrm{HCl} / \mathrm{HF}$. The 232 following features arise from our results:

233 (i) Well defined short-period co-oscillations of the volcanic gas temperature and of most 234 chemical ratios in the 8-32 sec band, sometimes extended to about $64 \mathrm{sec}$, that recur every $235 \sim 100$ to $200 \mathrm{sec}$ (Fig. 6);

236 (ii) A continuous modulation of all parameters at around $500 \mathrm{sec}(\sim 8 \mathrm{~min})$, especially well 237 characterized by $\mathrm{SO}_{2} / \mathrm{HCl}$ and $\mathrm{SO}_{2} / \mathrm{HF}$ ratios (Fig. 6). Less well defined modulations also appear in the $\sim 100-250 \mathrm{sec}$ period band.

239 (iii) Close co-variations of both $\mathrm{SO}_{2} / \mathrm{HF}$ and $\mathrm{HCl} / \mathrm{HF}$ ratios with the volcanic gas 240 temperature (Fig. 5a). Coherence tests (Fig. 7) verify a synchronous behaviour of these two 241 gas ratios at all periods and at almost all times (except in the $250-750 \mathrm{sec}$ window). $\mathrm{SO}_{2} / \mathrm{HCl}$ 242 ratio broadly co-varies with $\mathrm{SO}_{2} / \mathrm{HF}$ (Fig. 5b and 5c), especially at longer periodicity (Fig. 6), 243 while displaying fewer apparent oscillations at short periods.

244 (iv) Both highly correlated and poorly correlated variations of $\mathrm{CO}_{2} / \mathrm{HCl}$ and $\mathrm{CO}_{2} / \mathrm{SO}_{2}$ 245 ratios with respect to both $\mathrm{SO}_{2} / \mathrm{HCl}$ and $\mathrm{SO}_{2} / \mathrm{HF}$ (Figs. 5b-c and 6). Coherence tests using $246 \mathrm{HCl} / \mathrm{HF}$ as a reference do show a rare consistent behaviour of $\mathrm{CO}_{2} / \mathrm{SO}_{2}$ and $\mathrm{HCl} / \mathrm{HF}$ ratios at 247 short (8-64 sec) and long (500 sec) periods (Fig. 7), with a common phase shift (left-pointing 248 arrows) prevalently due to $\mathrm{CO}_{2} / \mathrm{SO}_{2}$ (down-pointing arrows). In particular, our time series 249 (Figs. 5b-c) reveal discrete spike increases of both $\mathrm{CO}_{2} / \mathrm{HCl}$ and $\mathrm{CO}_{2} / \mathrm{SO}_{2}$ (by a factor 2 to 4 ) 250 occurring at constant $\mathrm{S} / \mathrm{Cl} / \mathrm{F}$ ratios, which demonstrate intermittent episodes of selective $\mathrm{CO}_{2}$ 
enrichment of the volcanic gas. Such events are outlined between 03:07:59 and 03:10:22

252 during our first measuring sequence (Fig. 5b) and between 04:21:51 and 04:22:20 during our 253 second sequence (Fig. 5c). These $\mathrm{CO}_{2}$ spikes, lasting from $\sim 1$ to $2 \mathrm{~min}$, were observed to 254 coincide with the sequential bursting of very large (meter-sized) gas bubbles at the lake 255 surface.

\section{Discussion}

\subsection{Average composition of Benbow basaltic gas}

From Figure 3 and the air-corrected gas amounts in each spectrum we first derive the average molar composition of Benbow basaltic gas during our measurements. This composition (Table 1) is highly dominated by water vapor (96.1\%), followed by $\mathrm{CO}_{2}(2.2 \%)$, $\mathrm{SO}_{2}(1.1 \%), \mathrm{HCl}(0.35 \%), \mathrm{HF}(0.19 \%)$ and $\mathrm{CO}(0.01 \%)$. Except for $\mathrm{CO}$, reported here for the first time, we find that it is fairly comparable to the composition of cold Benbow plume emissions first analyzed with in situ methods in October 2007 (Allard et al., 2015). Despite completely different instrumental tools and data processing techniques, both data sets (Table 1) show closely similar $\mathrm{H}_{2} \mathrm{O}$ content, $\mathrm{SO}_{2} / \mathrm{HCl}(3.1 \pm 0.4$ versus $4.3 \pm 1.7)$ and $\mathrm{HCl} / \mathrm{HF}(1.9 \pm 0.3$ versus $2.3 \pm 0.3$ ) ratios, while possibly differing in a somewhat higher $\mathrm{CO}_{2} / \mathrm{SO}_{2}$ ratio in 2008 (2.0 \pm 1.4$)$ than $2007(1.0 \pm 0.2)$. This compositional resemblance for the same volcanic activity

271 but at a one-year interval thus suggests quite steady magma degassing conditions. Long-term 272 compositional gas stability at persistently active lava lakes, indicative of steady degassing 273 processes, is a feature previously verified from repeated OP-FTIR measurements at Masaya 274 (Burton et al., 2000), Nyiragongo (Sawyer et al., 2008a) and Erebus (Oppenheimer et al., 275 2009; Ilanka et al., 2015). 
The $\mathrm{CO} / \mathrm{CO}_{2}$ ratio of Benbow volcanic gas, measured for the first time, averages $4.7 \times 10^{-3}$

277 (Table 1). This ratio can be used to estimate the unknown redox conditions of Ambrym 278 basaltic system if the gas equilibration temperature is determined. We assess this temperature 279 from standard thermochemical data (Barin and Knacke, 1973) for the reaction: $3 \mathrm{CO}_{2}+\mathrm{H}_{2} \mathrm{~S}=$ $2803 \mathrm{CO}+\mathrm{SO}_{2}+\mathrm{H}_{2} \mathrm{O}$, assuming ideal gas behaviour and combining the $\mathrm{CO} / \mathrm{CO}_{2}$ ratio and $\mathrm{H}_{2} \mathrm{O}$ 281 molar proportion (0.96) measured in 2008 with the $\mathrm{SO}_{2} / \mathrm{H}_{2} \mathrm{~S}$ molar ratio of Benbow plume 282 measured in 2007 with MultiGas sensors. The latter ranged between 10 (A. Aiuppa, pers. comm. 2007) and $\geq 100$ (Allard et al., 2015). From these values we compute an apparent gas 284 equilibrium temperature of between $1085^{\circ} \mathrm{K}$ and $1022^{\circ} \mathrm{K}$ at ambient pressure. This is much 285 higher than the physical temperature of the volcanic gas $\left(340 \pm 20^{\circ} \mathrm{K}\right)$ derived from our FTIR 286 spectra (section 3), demonstrating a relatively fast chemical quenching of the cooling magmatic gas phase after emission. From the equilibrium reaction $\mathrm{CO}_{2}=\mathrm{CO}+1 / 2 \mathrm{O}_{2}$ at $1022-$ $1085^{\circ} \mathrm{K}$ and the $\mathrm{CO} / \mathrm{CO}_{2}$ ratio of Benbow gas, we then compute an oxygen fugacity of between -0.13 and +0.14 log-unit with respect to the NNO (nickel-nickel oxide) redox buffer.

290 Therefore, we infer that the redox state of Ambrym basaltic system may be close to NNO, which is also typical for the parental basalt of Siwi-Yasur magmatic system in southern Vanuatu (Métrich et al., 2011) and, more broadly, for basaltic arc volcanism (e.g. Kelley and 293 Cottrell, 2009).

\subsection{Lava lake degassing pattern and mechanisms}

Our OP-FTIR measurements performed at high temporal resolution and at short distance from Benbow lava lake provide unique insight into its degassing dynamics. The temporal variations in volcanic gas ratios reveal a highly dynamic degassing pattern (Figs. 5 and 6), involving both recurrent short-period ( $8-64 \mathrm{sec})$ compositional oscillations, a longer-period 
( $\sim 8 \mathrm{~min}$ ) continuous degassing modulation, and $\mathrm{CO}_{2}$-rich discrete events coinciding with the

302 bursting of large gas bubbles. Moreover, they reveal intervals of both coherence and

303 incoherence between the gas ratios (Figs. 5 and 7), indicating the bearing of quite different

304 physical processes at different times.

305 Because there is no permanent monitoring network on Ambrym, we cannot compare these

306 high frequency geochemical variations with other (e.g. geophysical) parameters recorded

307 synchronously. We therefore attempt to interpret them on basis of our field observations and

308 melt inclusion data recently obtained for Ambrym arc basalt (Allard et al., 2015). The basalt

309 was found to be moderately rich in volatiles (e.g. $\sim 1.2 \mathrm{wt} \% \mathrm{H}_{2} \mathrm{O}$ and $0.1 \mathrm{wt} \% \mathrm{CO}_{2}$ ) and to

310 prevalently degas in closed system upon ascent from a crustal reservoir emplaced at about 4

$311 \mathrm{~km}$ beneath Benbow and Marum vents (Allard et al., 2015). Whereas $\mathrm{CO}_{2}$ and sulphur start to

312 exsolve at high pressures ( $\sim 200 \mathrm{MPa}$ and $<150 \mathrm{MPa}$, respectively), $\mathrm{H}_{2} \mathrm{O}, \mathrm{Cl}$ and plausibly $\mathrm{F}$

313 (not analysed) mainly exsolve at low to very low pressure during this process (Allard et al.,

314 2015). These contrasted solubility behaviours in the melt are reflected in the P-related

315 compositional evolution of the co-existing magmatic gas phase (Fig. 8), computed using

316 VolatileCalc (Newman and Lowenstern, 2002) and the $\mathrm{K}_{2} \mathrm{O}$-normalized volatile content of the

317 melt inclusions (see details in Figure 8's caption). While a bulk magma degassing process

318 well reproduces the average composition of Benbow volcanic gas, the results reveal sharp

319 variations in the total gas volume fraction, $\mathrm{H}_{2} \mathrm{O} / \mathrm{CO}_{2}$ and $\mathrm{S} / \mathrm{Cl}$ ratios associated with the

320 prominent degassing of $\mathrm{H}_{2} \mathrm{O}$ and $\mathrm{Cl}$ at low pressures of between 25 and $<10 \mathrm{MPa}$ (Fig. 8).

321 Below we use these observations to interpret the degassing pattern of Benbow lava lake.

322 We first notice that the recurrent $(\sim 100-200 \mathrm{sec})$ short-period oscillations of Benbow gas

323 temperature and composition (Fig. 6) match well the observed puffing activity of the lava

324 lake. Their frequency, together with the relatively modest amplitude of variation of each

325 parameter around its time-averaged value (Figs. 5a and 5c), point to a shallow degassing 
process sourced within the upper portion of the lava lake. We do interpret these recurrent short-term variations as reflecting the periodic bursting of S-rich (high $\mathrm{S} / \mathrm{Cl}$ and $\mathrm{S} / \mathrm{F}$ ratios) and S-depleted (low $\mathrm{S} / \mathrm{Cl}$ and $\mathrm{S} / \mathrm{F}$ ratios) gas bubbles associated with the alternation, at the lake surface, of fresh lava blobs and partly degassed (S-depleted but still Cl-F-bearing), less

330 hot lava. This interpretation is consistent with the modest amplitude of $\mathrm{S} / \mathrm{Cl}$ fluctuations (from 2.5 to 4 ) around a mean value of $3.1 \pm 0.4$ (Fig. 3a), which imply a very shallow degassing process (Fig. 8). It also well accounts for the temporal changes in degassing intensity inferred from the anti-correlated variations in atmospheric path length and total volcanic gas amount (Fig. 4 and Section 3.1). In this framework, the $\sim 100-200 \mathrm{sec}$ recurrence of the short-lived Tgas oscillations represents a time scale of convective resurfacing of the lava lake during our measurements.

Instead, the continuous modulation of almost all parameters with $\sim 8 \min$ period, especially well defined by $\mathrm{SO}_{2} / \mathrm{HCl}$ and $\mathrm{SO}_{2} / \mathrm{HF}$ ratios (Fig. 6), evidences a constant degassing periodicity of the volcanic system. Because it concerns all gas ratios this persistent dynamic signature likely typifies a somewhat deeper process involving both the lava lake and its feeder conduit. A plausible mechanism is the continuous influx of bubble-rich magma to the bottom of the lake, whose rate will determine the renewal time of the latter. The magma supply rate to

343 Benbow crater was estimated to be as high as $\sim 20 \mathrm{~m}^{3} \mathrm{~s}^{-1}$ from the $\mathrm{SO}_{2}$ flux emitted by this 344 crater in October 2008 (see section 4.3) and from the magma sulfur content (Allard et al., 345 2015). If the degassing periodicity of $\sim 8 \mathrm{~min}$ is taken to approximate the renewal time of the lava lake controlled by this supply rate, we infer a lake volume of $\sim 10^{4} \mathrm{~m}^{3}$, about twice that 347 of Erebus lava lake (Oppenheimer et al., 2009).

348 Finally, we invoke a deeper, conduit source for the discrete $\mathrm{CO}_{2}$ degassing events 349 characterized by sharp spike increases of $\mathrm{CO}_{2} / \mathrm{HCl}$ and $\mathrm{CO}_{2} / \mathrm{SO}_{2}$ at constant $\mathrm{S} / \mathrm{Cl} / \mathrm{F}$ ratios 350 (Figs. 5b and 5c). The chemical amplitude of these intermittent events, their duration $(\sim 1-2$ 
min) and their coincidence with the bursting of series of meter-sized bubbles at the lake surface strongly suggest the separate ascent, in Benbow conduit, of large gas bubbles or slugs preferentially enriched in early exsolved $\mathrm{CO}_{2}$ (Fig. 8). This means that, despite prevalent closed-system degassing of the basalt upon ascent, bubble accumulation and modest coalescence would also occur at some depth in the feeding system. A quantitative estimate is however impossible at present owing to the natural lack of $\mathrm{CO}_{2}$-bearing melt inclusions trapped at less than $\sim 75 \mathrm{MPa}$ (Allard et al., 2015).

The diameter of Benbow conduit can tentatively be estimated from the magma supply rate of $\sim 20 \mathrm{~m}^{3} \mathrm{~s}^{-1}$ mentioned above. Extensive convection in Benbow feeding system, with downward recycling of the denser degassed magma, is required to accommodate for such a rate, little of which exits as lava clots and ash (Allard et al., 2015). Magma convection is also supported by the textural features of Benbow eruptive products (Polacci et al., 2012). Here we focus on the uppermost conduit, assumed to be vertical and cylindrical for the sake of simplicity. As shown by Beckett et al. (2014), the net volumetric flux (Q) of magma upraising in a vertical conduit with bi-directional exchange flow does not depends on the flow regime and can be approximated by the following relationship:

$$
Q=0.059 \beta^{-0.74}\left(\frac{g \Delta \rho R^{4}}{2 \mu_{b}}\right)
$$

where $\beta$ is the viscosity ratio between the degassed and the volatile-rich buoyant magma components, $\Delta \rho$ is their difference in density, $\mu_{b}$ is the dynamic viscosity of the buoyant component, $g$ is gravitational acceleration and $R$ is the effective conduit radius. We use the rhyolite-MELTS $+\mathrm{H}_{2} \mathrm{O}-\mathrm{CO}_{2}$ software (version 1.2.x; Ghiorso and Gualda, 2015) to compute magma densities and viscosities at a temperature of $1400^{\circ} \mathrm{K}$ which, under NNO redox conditions (such as inferred in section 4.1), well accounts for the melt composition, the low crystal content ( $<5$ to $10 \%$ ) and the mineral chemistry of Benbow products (Allard et al., 2015; N. Métrich, unpub. data, 2012; Picard et al., 1995). As shown in Figure 8, during its 
closed-system ascent Ambrym basalt will reach 50\% vesicularity - a threshold for permeability-controlled gas percolation and hence open degassing (Burton et al., 2007b) while decompressing to only about $10 \mathrm{MPa}$. Under these conditions the buoyant magma has a density of $\sim 1500 \mathrm{~kg} \mathrm{~m}^{-3}$ and an effective viscosity of $595.5 \mathrm{~Pa} \mathrm{~s}$ if one assumes spherical380 shaped bubbles and a low capillary number (Pal, 2002). Once degassed at or near the surface 381 of the lake, the magma becomes much denser $\left(2700 \mathrm{~kg} \mathrm{~m}^{-3}\right)$ and more viscous (1445 $\left.\mathrm{Pa} \mathrm{s}\right)$ 382 and, therefore, should rapidly sink down the lake and the feeder conduit. From these numbers and the above equation we compute a diameter of $6 \pm 1 \mathrm{~m}$ for Benbow upper conduit, taking account of propagating uncertainties on the different parameters. Before entering the lava lake, the buoyant basalt would flow at $1.4 \mathrm{~m} \mathrm{~s}^{-1}$ across the inner half section of the conduit, which is a favourable condition to maintain bubble-melt coupling up to very shallow depth.

Finally, we emphasize that the degassing pattern of a vigorously active basaltic lake on Ambrym markedly differs from that recorded during quieter lava lake activity at either Erebus or Kilauea, the only two volcanoes where detailed OP-FTIR investigations have been achieved until now. At Erebus, passive degassing with relatively constant composition was

391 found to prevail between the explosive bursting of deeper-derived large gas bubbles or slugs 392 happening every $\sim 10 \mathrm{mn}$ (Oppenheimer et al., 2009; Ilanka et al., 2015), while at Kilauea $\sim 30$ 393 $\mathrm{mn}$ long cycles of low passive degassing and lava lake upheaval, controlled by shallow 394 bubble accumulation (gas pistoning), were observed to alternate with intervals of spattering 395 and increased $\mathrm{H}_{2} \mathrm{O}-\mathrm{SO}_{2}$-rich gas release after a sudden drop in lake level (Patrick et al., 2016). 396 With an estimated volume of $10^{4} \mathrm{~m}^{3}$, an upper (surface) diameter of $\sim 25 \mathrm{~m}$ and a lower 397 (conduit) diameter of $\sim 6 \mathrm{~m}$, Benbow lava lake (as an inverted truncated cone) would have 398 had a modest height of $\sim 12 \mathrm{~m}$ in October 2008. Such small dimensions, coupled with the high 399 basalt supply rate of $\sim 20 \mathrm{~m}^{3} \mathrm{~s}^{-1}$, well explain its vigorous degassing and rapid renewal rate. 400 Instead, the much quieter degassing patterns of lava lakes at Kilauea and Erebus is fully 
consistent with their longer renewal rate (about 4 days and 4 hours, respectively; Patrick et al., 2016; Oppenheimer et al., 2009), due to a lower magma supply rate but also a much larger size for Kilauea basaltic lake $\left(2.5 \times 10^{6} \mathrm{~m}^{3}\right.$ and $100 \mathrm{~m}$ deep in 2010; Carbone et al., 2013) and a much higher viscosity in case of Erebus phonolite lake (Oppenheimer et al., 2009).

4.3 Ambrym volcanic gas composition and emission rates compared with other lava lakes worldwide

Ambrym basaltic gas from Benbow lava lake in October 2008 is compared in Table 1 with magmatic gases from other active lava lakes measured with OP-FTIR spectroscopy and/or classical (in situ) methods. Ambrym basaltic gas is markedly richer in water and halogens than hot spot or rift basaltic gases from Kilauea and Erta'Ale lava lakes, respectively, whilst being poorer in $\mathrm{CO}_{2}$ than magmatic gases from Nyiragongo and Erebus alkaline lakes. These features are coherent with differences in magma compositions and geodynamic contexts. Ambrym volcanic gas more closely resembles arc volcanic gases from Masaya (Burton et al., 2000) and Villarrica (Sawyer et al., 2011) lava lakes (Table 1) and typically plots within the compositional field for arc volcanism for both major components and trace halogen species (Allard et al., 2015).

Airborne DOAS measurements on 8 October 2008 revealed a total $\mathrm{SO}_{2}$ plume flux of $\sim 100 \pm 30 \mathrm{~kg} \mathrm{~s}^{-1}$ from the volcano, $75 \%$ of which arose from Benbow and $25 \%$ from Marum craters (Allard et al., 2015). Combining the specific $\mathrm{SO}_{2}$ flux from Benbow $\left(\sim 75 \mathrm{~kg} \mathrm{~s}^{-1}\right.$, or $6500 \mathrm{Mg} \mathrm{d}^{-1}$ ) with the average gas composition measured with OP-FTIR spectroscopy (Table 1), we compute the simultaneous emission of $1.6 \times 10^{5} \mathrm{Mg} \mathrm{d}^{-1}$ of $\mathrm{H}_{2} \mathrm{O}, 9 \times 10^{3} \mathrm{Mg} \mathrm{d}^{-1}$ of $\mathrm{CO}_{2}$, $1.2 \times 10^{3} \mathrm{Mg} \mathrm{d}^{-1}$ of $\mathrm{HCl}, 350 \mathrm{Mg} \mathrm{d}^{-1}$ of $\mathrm{HF}$ and $8 \mathrm{Mg} \mathrm{d}^{-1}$ of $\mathrm{CO}$ (with overall $\pm 30 \%$ uncertainty; Table 2). Such gas emission rates are far larger than those from most other lava lakes. For 
instance, Benbow fluxes of $\mathrm{H}_{2} \mathrm{O}, \mathrm{HCl}$ and $\mathrm{HF}$ exceed by factors as high as 190-670, 50-460 and 17-1000 the ranges in corresponding fluxes from Erebus, Kilauea and Erta'Ale lava lakes

428

429

430 (Table 2). In terms of $\mathrm{H}_{2} \mathrm{O}, \mathrm{CO}_{2}$ and $\mathrm{SO}_{2}$ fluxes, whose sum approximates the total gas flux, Benbow crater (and Ambrym as a whole) is of comparable strength as Nyiragongo (Sawyer et al., 2008a), despite widely differing magma compositions. The $\mathrm{CO}_{2}$ discharge of $\sim 10 \mathrm{Gg}$ per day from Benbow in October 2008 actually ranks amongst the highest known emissions of igneous carbon from persistently degassing volcanoes (Burton et al., 2013). As a matter of fact, our study provides further evidence that Ambrym volcano ranks among the top-three persistent emitters of magma-derived volatiles at a global scale, together with Nyiragongo and Etna (Table 2). In addition to their impact on local ecosystems (Bani et al., 2009; Allibone et al., 2012), volcanic gas emissions from Ambrym may thus have a considerable atmospheric impact at regional scale in the southwest Pacific (Lefèvre et al., 2015).

\section{Conclusions}

We performed the first OP-FTIR measurements of gas emissions from Benbow crater on Ambrym volcano, in Vanuatu. Ambrym is one of the rare basaltic arc volcanoes displaying persistent lava lake activity, but has long remained undocumented for its degassing compared to other, more accessible lava lakes worldwide. We measured gas absorption spectra at short range $(\sim 140 \mathrm{~m})$ using the vigorously active Benbow lava lake itself as a radiation source. Analysis of these spectra allowed retrieval of volcanic $\mathrm{H}_{2} \mathrm{O}, \mathrm{CO}_{2}, \mathrm{SO}_{2}, \mathrm{HCl}, \mathrm{HF}$ and $\mathrm{CO}$ path amounts at high temporal resolution ( $5 \mathrm{sec}$ period). Our gas composition data were combined with simultaneously measured $\mathrm{SO}_{2}$ fluxes to quantify fluxes for each measured magmatic gas species from Ambrym.

We outline the following main observations: 
(i) Lava lake degassing at Ambrym clearly differs in its water-halogen-rich average composition from basaltic or alkaline volcanic gases from long-lived lava lakes on rifting plate boundaries (Erta'Ale, Nyiragongo, Erebus) or hot spots (Kilauea). It more closely resembles volcanic gases from other basaltic arc volcanoes, in agreement with Ambrym' subduction zone setting.

(ii) Temporal variations of Benbow volcanic gas composition during our measuring interval reveal a highly dynamic degassing pattern of the lava lake. Short-period oscillations of most ratios, recurring every $\sim 100-200 \mathrm{sec}$, match the observed pulsated degassing (puffing) of the lake. These oscillations, especially clear and coherent for $\mathrm{SO}_{2} / \mathrm{HF}, \mathrm{HCl} / \mathrm{HF}$ and $\mathrm{SO}_{2} / \mathrm{HCl}$ ratios and correlated with temperature variations, indicate an inside-lake shallow degassing process marked by the periodic bursting of S-rich (high $\mathrm{S} / \mathrm{Cl}$ ratio) and $\mathrm{S}$-depleted (low $\mathrm{S} / \mathrm{Cl}$ ) gas bubbles associated with the alternation of fresh lava and degassed lava at the lake surface. A longer-period $(\sim 8 \mathrm{~min})$ persistent modulation of the gas ratios, particularly well characterized for $\mathrm{SO}_{2} / \mathrm{HF}$ and $\mathrm{SO}_{2} / \mathrm{HCl}$, probably tracks the influx of bubble-rich magma at the bottom of the lake and thus the rate of convective renewal of this latter. Occasional sharp increases of $\mathrm{CO}_{2} / \mathrm{HCl}$ and $\mathrm{CO}_{2} / \mathrm{SO}_{2}$ at constant $\mathrm{S} / \mathrm{Cl} / \mathrm{F}$ ratios, lasting 1-2 min, evidence discrete degassing events during which carbon dioxide was selectively enriched in the emitted gas. These events, coinciding with the bursting of meter-sized bubbles at the lake surface, are attributed to the separate ascent of deeper derived $\left(\mathrm{CO}_{2}\right.$-rich) large gas bubbles or slugs in Benbow feeder conduit, the diameter of which is estimated as $6 \pm 1 \mathrm{~m}$.

(iii) The highly dynamic degassing pattern of Benbow basaltic lake markedly differs from that of quieter lava lakes at either Kilauea or Erebus. In first order, this can be related to a smaller size and much faster renewal rate of Benbow lava lake, due to a very high basalt 
supply rate, compared to Kilauea basaltic lake, and to a much lower magma viscosity

476 when compared to the phonolite lake of comparable size occurring at Erebus.

477 (iv) Gas emission rates from Benbow crater in October 2008 include $160 \mathrm{Gg} \mathrm{d}^{-1}$ of $\mathrm{H}_{2} \mathrm{O}$, $478 \sim 10 \mathrm{Gg} \mathrm{d}^{-1}$ of $\mathrm{CO}_{2}$ and $\sim 8 \mathrm{Gd} \mathrm{d}^{-1}$ of total acid gases $\left(\mathrm{SO}_{2}, \mathrm{HCl}\right.$ and $\left.\mathrm{HF}\right)$. Such emission 479 rates are far larger than those from other lava lakes currently active worldwide, with the 480 exception of Nyiragongo lava lake on the East African rift. We further verify that 481 Ambrym volcano actually ranks amongst the three most powerful persistent emitters of 482 volcanic gases at global scale and, hence, may have a considerable environmental impact 483 in the southwest Pacific region.

484 Our study of lava lake degassing on Ambrym arc volcano further illustrates the great 485 potential of OP-FTIR spectroscopy to investigate magma degassing processes at high 486 temporal resolution. It reveals an unprecedented dynamism in gas emissions from a basaltic 487 lake, reflecting the superimposed processes of coupled and decoupled ascent of magma and 488 gas which feed this remarkable volcanic system. Such new insights into shallow magma 489 dynamics at a highly active basaltic volcano provide a valuable basis for quantitative 490 interpretation and modeling of gas composition variations and magma dynamics at other lava 491 lakes and open-vents basaltic volcanoes. 


\section{Acknowledgements}

Our study was supported by the French National Agency for Research, through 2007-2010 contracts "VOLGASPEC" (06-CATT-012-01) and "Arc Vanuatu" (06-CATT-012-002), and benefited from funding from the European Research Council (FP/2007-2013)/ERC Grant Agreement n. 279802). We acknowledge B. Pelletier (IRD, Noumea), E. Garaebiti (GEOHAZARD, Vanuatu), guides and porters from Ambrym's Lalinda village for local assistance, and G. Tamburello (Palermo University, Italy) for its help in Morlet wavelet analysis. Thorough reviews by K. Iacovino, M. Patrick and two anonymous referees, as well as careful editing by T. Mather, greatly improved our manuscript. 


\section{References}

Allard, P., Burton, M., Murè, F., 2005. Spectroscopic evidence for a lava fountain driven by previously accumulated magmatic gas. Nature $43,7024,407-410$.

Allard, P., Aiuppa A., Bani P., Métrich N., Bertagnini A., Gauthier P-J., Shinohara H., Sawyer G., Parello F., Bagnato E., Pelletier B., Garaebiti, E., 2015. Prodigious emission rates and magma degassing budget of major, trace and radioactive volatile species from Ambrym basaltic volcano, Vanuatu island Arc. J. Volcanol. Geotherm. Res., special issue on Vanuatu Volcanoes, doi:10.1016/j.jvolgeores.2015.08.022.

Allibone, R., Cronin, S. J., Charley, D. T., Neall, V. E., Stewart, R. B., Oppenheimer, C., 2012. Dental fluorosis linked to degassing of Ambrym volcano, Vanuatu: A novel exposure pathway. Environ. Geochem. Health 34(2), 155-170, doi: 10.1007/s10653-010-9338-2.

Bani, P., Oppenheimer, C., Tsanev, V.I., Carn, S.A., Cronin, S.J., Crimp, R., Charley, D., Lardy, M., Roberts, T.R., 2009. Surge in sulphur and halogen degassing from Ambrym volcano, Vanuatu. Bull. Volcanol. 71, 10, 1159-1168, doi:10.1007/s00445-009-0293-7.

Bani, P., Oppenheimer, C., Allard, P., Shinohara, H., Lardy, M., Garaebiti, E., 2012. First estimate of volcanic $\mathrm{SO}_{2}$ budget for Vanuatu island arc. J. Volcanol. Geotherm. Res 211-212, 36-46, doi: 10.1016/j.jvolgeores.2011.10.005.

Barin, I., Knacke, O., 1973. Thermochemical Properties of Inorganic Substances. Springer Verlag, Berlin, $921 \mathrm{pp}$. 
Beckett, F.M., Burton M., Mader, H.M., Phillips, J.C., Polacci, M., Rust, A.C., Witham, F., 2014. Conduit convection driving persistent degassing at basaltic volcanoes. J. Volcanol. Geotherm. Res. 283, 19-35, doi:10.1016/j.jvolgeores.2014.06.006.

Bouche, E., Vergniolle, S., Staudacher, T., Nercessian, A., Delmont, J.-C., Frogneux, M., Cartault, F., Le Pichon, A., 2010. The role of large bubbles detected from acoustic measurements on the dynamics of Erta 'Ale lava lake (Ethiopia). Earth Plan. Sci. Lett. 295, 37-48.

Burton, M., Oppenheimer, C., Horrocks, L.A., Francis, P.W., 2000. Field measurement of $\mathrm{CO}_{2}$ and $\mathrm{H}_{2} \mathrm{O}$ emissions from Masaya Volcano, Nicaragua, by Fourier transform spectrometry. Geology 28, 915-918.

Burton, M., Allard, P., Murè, F., La Spina, A., 2007a. Magmatic gas composition reveals the source depth of slug-driven Strombolian explosive activity. Science 317, 5835, 227-230, doi:10.1126/science.114190.

Burton, M.R., Mader, H.M., Polacci, M., 2007b. The role of gas percolation in quiescent degassing of persistently active basaltic volcanoes. Earth Plan. Sci. Lett. 264, 1-2, 46-60, doi:10.1016/j.eps1.2007.08.028.

Burton, M., Sawyer, G.M., Granieri, D., 2013. Deep carbon emissions from volcanoes. Reviews in Mineral. Geochem. 75, 323-354.

Carbone, D., Poland, M.P., Patrick, M.R., Orr, T.R., 2013. Continuous gravity measurements reveal a low-density lava lake at Kilauea Volcano, Hawaii. Earth Planet. Sci. Lett. 376, 178-185. 
Commonwealth Scientific and Industrial Research Organisation (CSIRO), Australia, http://www.csiro.au/greenhouse-gases/, (ftp://gaspublic:gaspublic@,ftp.dar.csiro.au/data/gaslab/), October 2008.

Edmonds, M., Gerlach, T.M., 2007. Vapor segregation and loss in basaltic melts. Geology 35, 8, 751754.

Edmonds, M., Sides, I.R., Swanson, D.A., Werner, C., Martin, R.S., Mather, T.A., Herd, R.A., Jobes, R.L., Mead, M.I., Sawyer, G., Roberts, T.J., Sutton, A.J., Elias, T., 2013. Magma storage, transport and degassing during the 2008-10 summit eruption at Kilauea volcano, Hawaii. Geochim. Cosmochim. Acta 123, 284-301, http://dx.doi.org/10.1016/j.gca.2013.05.038.

Edwards, D.J., Dudhia, A., 1996. Reference Forward Model: High level algorithms definition. ESA document PO-MA-OXF-GS-0004.

Gerlach, T.M., Graeber, E.J., 1985. Volatile budget of Kilauea volcano. Nature 313, 273-277.

Giggenbach, W.F., Le Guern, F., 1976. The chemistry of magmatic gases from Erta 'Ale, Ethiopia. Geochim. Cosmochim. Acta 40, 25-30.

Ghiorso, M.S., Gualda, G.A.R., 2015. An $\mathrm{H}_{2} \mathrm{O}-\mathrm{CO}_{2}$ mixed fluid saturation model compatible with rhyolite-MELTS. Contrib. Mineral. Petrol. 169, 53, DOI 10.1007/s00410-015-1141-8.

Grinsted A., Moore, J.C., Jevrejeva, S., 2004. Application of the cross wavelet transform and wavelet coherence to geophysical time series. Nonlinear Process Geophys. 11, 561-566, doi:10.5194/npg11-561-2004. 
Harris, A.J.L., Flynn, L.P., Rothery, D.A., Oppenheimer, C., Sherman, S.B., 1999. Mass flux measurements at active lava lakes: Implications for magma recycling. J. Geophys. Res. 104, 7117 7136.

Ilanko, T., Oppenheimer, C., Burgisser, A., Kyle, P., 2015. Cyclic degassing of Erebus volcano, Antarctica. Bull. Volcanol. 77, 56-71, doi:10.1007/s00445-015-0941-z.

Kazahaya, K., Shinohara, H., Saito, G., 1994. Excessive degassing of Izu-Oshima volcano: magma convection in a conduit. Bulletin of Volcanology 56, 207-216.

Kelley, K.A., Cottrell, E., 2009. Water and the oxidation state of subduction zone magmas. Science 31, 325, 5940, 605-607, doi:10.1126/science.1174156.

La Spina, A., Burton, M., Allard, P., Alparone, S., Murè, F., 2015. Open-path FTIR spectroscopy of magma degassing processes during eight lava fountains on Mount Etna. Earth Plan. Sci. Lett. 413, 123-134, doi: dx.doi.org.10.1016.j.eps1.2014.12.038.

Lefèvre, J., Menkes, C., Bani, P., Marchesiello, P., Curci, G., Grell, G.A., Frouin, R., 2015. Distribution of sulfur aerosol precursors in the SPCZ released by continuous volcanic degassing at Ambrym, Vanuatu. J. Volcanol. Geotherm. Res., http://dx.doi.org/10.1016/j.jvolgeores.2015.07.018, in press.

Le Guern, F., Carbonnelle, J., Tazieff, H., 1979. Erta 'Ale lava lake: heat and gas transfer to the atmosphere. J. Volcanol. Geotherm. Res. 6, 27-48.

MacCall, G.J.H., Le Maitre, R.W., Madoff, A., Robinson, G.P., Stephenson, P.J., 1970. The geology and geophysics of the Ambrym caldera, New Hebrides. Bull. Volcanol. 34, 681-696.

Métrich, N., Allard, P., Aiuppa, A., Bani, P., Bertagnini, A., Belhadj, O., Di Muro, A., Garaebiti, E., 
Massare, D., Parello, F., Shinohara, H., 2011. Magma and volatile supply to post-collapse volcanism and block resurgence in Siwi caldera (Tanna island, Vanuatu arc). J. Petrol. 52, 10771105, doi:10.1093/petrology/egr019.

Newman, S., Lowenstern, J.B., 2002. VolatileCalc: a silicate melt- $\mathrm{H}_{2} \mathrm{O}-\mathrm{CO}_{2}$ solution model written in Visual Basic for excel. Comput. Geosci. 28, 597- 604.

Moussallam, Y., Oppenheimer, C., Scaillet, B., Buisman, I., Kimball, C., Dunbar, N., Burgisser, A., Schipper, C.I., Andújar, J., Kyle, P., 2015. Megacrystals track magma convection between reservoir and surface. Earth Plan. Sci. Lett. 413, 1-12, dx.doi.org/10.1016/j.epsl.2014.12.022.

Oppenheimer, C., McGonigle, A.J.S., Allard, P., Wooster, M.J., Tsanev, V., 2004. Sulfur, heat, and magma budget of Erta 'Ale lava lake, Ethiopia. Geology 32, 6, 509-512.

Oppenheimer, C., Kyle, P.R., 2008. Probing the magma plumbing of Erebus volcano, Antarctica, by open-path FTIR spectroscopy of gas emissions. J. Volcanol. Geotherm. Res. 177 (3), 743-754, doi: 10.1016/j.jvolgeores.2007.08.022.

Oppenheimer, C., Lomakina, A.S., Kyle, P.R., Kingsbury, N.G., Boichu, M., 2009. Pulsatory magma supply to a phonolite lava lake. Earth Plan. Sci. Lett. 284, 392-398, doi:10.1016/j.eps1.2009.04.043.

Pal, R., 2002. Rheological behaviour of bubble-bearing magmas. Earth Planet. Sci. Lett. 207, 165179.

Patrick, M.R., Orr, T., Sutton, A.J., Lev, E., Thelen, W., Fee, D., 2016. Shallow driven fluctuations in lava lake outgassing (gas pistoning), Kilauea volcano. Earth Planet. Sci. Lett. 433, 326-338, http://dx.doi.org/10.1016/j.eps1.2015.10.052. 
Picard, C., Monzier, M., Eissen, J.-P., Robin, C., 1995. Concomitant evolution of tectonic environment and magma geochemistry, Ambrym volcano (Vanuatu, New Hebrides arc). In: Smellie, J.L. (Ed.), Volcanism associated with extension at consuming plate margin, Geol. Soc. America, Special Pub., pp. 135-154.

Polacci, M., Baker, D.R., La Rue, A., Mancini, L., Allard, P., 2012. Degassing behaviour of vesiculated basaltic magmas: an example from Ambrym volcano, Vanuatu Arc. J. Volcanol. Geotherm. Res. 233-234, 55-64, doi:10.1016/j.jvolgeores.2012.04.019.

Rodgers, C.D., 1976. Retrieval of atmospheric temperature and composition from remote measurements of thermal radiation. Rev. Geophys. 14, 4, 609-624.

Rothman, L.S. et al., 2005. The HITRAN 2004 molecular spectroscopic database. J. Quantit. Spectr. Radiat. Transfer 96, 2,139-204.

Sawyer, G.M., Carn, S.A., Tsanev, V., Oppenheimer, C., Burton, M., 2008a. Investigation into magma degassing at Nyiragongo volcano, Democratic Republic of the Congo. Geochem. Geophys. Geosyst. 9, 2, Q02017, doi: 10.1029/2007GC001829.

Sawyer, G.M., Oppenheimer, C., Tsanev, V.I., Yirgu, G., 2008b. Magmatic degassing at Erta'Ale volcano, Ethiopia. J. Volcanol. Geotherm. Res. 187, 837-846, doi: 10.1016/j.jvolgeores.2008.09.017.

Sawyer, G.M., Salerno, G., Le Blond, J.S., Martin, R.S., Spampinato, L., Roberts, T.J., Mather, T.A., Witt, M.L.I., Tsanev, V.I., Oppenheimer, C., 2011. Gas and aerosol emissions from Villarrica volcano, Chile. J. Volcanol. Geotherm. Res. 203, 62-75, doi:10.1016/j.jvolgeores.2011.04.003. 
Shinohara, H., Witter, J.B., 2005. Volcanic gases emitted during mild Strombolian activity of Villarrica volcano, Chile. Geophys. Res. Lett. 32, L20308, doi:10.1029/ 2005GL024131.

Shinohara, H., Fukui, K., Kazahaya, K., Saito, G., 2003. Degassing process of Miyakejima volcano: Implications of gas emission rate and melt inclusion data. In: De Vivo, B., Bodnar, B. (Eds), Melt Inclusions in Volcanic Systems, Dev. Volcanol. Ser., vol. 5, Elsevier, New York, pp. 147-161.

Stevenson, D.S., Blake, S., 1998. Modelling the dynamics and thermodynamics of volcanic degassing. Bull. Volcanol. 60, 307-317.

Tamburello, G., Aiuppa, A., Mcgonigle, A.J.S., Allard, P., Cannata, A., Kantzas, E.P., 2013. Periodic volcanic degassing behavior: Mount Etna example. Geophys. Res. Lett. 40, 4818-4822, doi:10.1002/grl.50924.

Tazieff, H., 1994. Permanent lava lakes: observed facts and induced mechanisms. J. Volcanol. Geotherm. Res. 63, 3-11, doi:10.1016/0377-0273(94)90015-9.

Torrence C., Compo, G.P., 1998. A practical guide to wavelet analysis. Bull. Am. Meteorol. Soc. 79, 61-78, doi:10.1175/1520-0477(1998)079\%3C0061:APGTWA\%3E2.0.CO;2.

Witham, F., Llewellin, E.W., 2006. Stability of lava lakes. J. Volcanol. Geotherm. Res. 158, 321-332, doi:10.1016/ j.jvolgeores.2006.07.004. 


\section{List and captions of Tables and Figures}

\section{$\underline{\text { Tables }}$}

Table 1 - Molar composition of Ambrym's basaltic gas from Benbow lava lake in October 2008 and October 2007, compared with volcanic gases from other basaltic arc volcanoes and from lava lakes active in different geodynamic contexts.

* Mean composition of Benbow gas from two field surveys on October 14 and 26, 2007. In situ: standard gas sampling/analysis methods. nd: not determined; bd: below detection. EAR: East African Rift. Data sources: (1) This work; (2) Allard et al., 2015; (3) Burton et al., 2000; (4) Sawyer et al., 2011; (5) Shinohara and Witter, 2005; (6) Shinohara et al., 2003; (7) Burton et al., 2007a, passive degassing; (8) Allard et al., 2005, lava fountain; (9) Giggenbach and Le Guern, 1974; (10) Sawyer et al., 2008b; (11) Edmonds and Gerlach, 2007; (12) Gerlach and Graeber, 1985; (13) Oppenheimer and Kyle, 2008; (14) Sawyer et al., 2008a.

Table 2 - Gas emission rates from Ambrym in 2007 and 2008, compared to gas emissions rates from other lava lakes worldwide.

Data sources: (1) This work; (2) Allard et al., 2015, bulk Ambrym emissions; (3) Burton et al., 2000; (4) Sawyer et al., 2011; (5) Sawyer et al., 2008b; (6) Edmonds et al., 2013; (7) Oppenheimer and Kyle, 2008; (8) Sawyer et al., 2008a.

\section{Figures}

Figure 1 - Ambrym volcano and its degassing lava lake in Benbow crater.

(a) Location of Ambrym volcano in the central part of Vanuatu island arc, affected by collision with the D'Entrecasteaux Ridge (DER) (modified from Allard et al., 2015). The insert shows the location of 
Vanuatu arc with respect to Australia and to the Cap Ferguson CSIRO air monitoring station $\left(19.28^{\circ} \mathrm{S}\right.$, $147.05^{\circ} \mathrm{E}$; see section 3); (b) Digital elevation model of Ambrym island showing the summit caldera and the two main active cones, Benbow (B) and Marum (M); (c) Inner structure of Benbow cone viewed from its southeast rim and location of its active lava lake in 2007-2008; (d) Degassing Benbow lava lake ( $25 \mathrm{~m}$ wide). Photo credit: P. Allard.

Figure 2 - Schematic drawing of OP-FTIR spectroscopic measuring conditions at the bottom of Benbow crater in October 2008.

Distances were measured with laser range-finding binoculars (Wilco LRB 4000-VCE). Slanting distance from our spectrometer to the center of lava lake averaged $140 \pm 10 \mathrm{~m}$. The spectrometer was inclined on its tripod at an angle of $58^{\circ}$ below horizontal and, given its $20 \mathrm{mrad}$ field of view, measured IR radiation emitted by a $\sim 7 \mathrm{~m}^{2}$ area of the degassing lake. The southern crater wall behind the lava lake was distant by $170 \mathrm{~m}$. The drawing illustrates the ejection of lava lumps, sometimes reaching the crater floor, and the intermittent sequential bursting of very large (meter-sized) gas bubbles.

Figure 3 a-d - Scatter plots of measured gas path amounts: (a) $\mathrm{SO}_{2}$ versus $\mathrm{HCl}$, (b) $\mathrm{HCl}$ versus $\mathrm{HF}$, (c) $\mathrm{CO}_{2}$ versus $\mathrm{SO}_{2}$ and (d) $\mathrm{H}_{2} \mathrm{O}$ versus $\mathrm{HF}$.

The gradient of linear regression in each plot defines the average molar ratio between the gas species in the pure volcanic gas. In Figures $3 c$ and $3 d$ the $y$-intercept of regression line indicates the average background amount of $\mathrm{CO}_{2}$ and $\mathrm{H}_{2} \mathrm{O}$ in ambient air of the pit crater. Error bars indicates the overall uncertainty $(1 \sigma)$ for each species. See section 3.2.

Figure 4 - Time series of the pure volcanic gas amounts, the gas temperature and the atmospheric optical path length for each spectrum during OP-FTIR measurement of Benbow lava lake degassing. 
$\mathrm{H}_{2} \mathrm{O}, \mathrm{CO}_{2}$ and $\mathrm{CO}$ amounts are corrected for air dilution. Details on retrieval of the volcanic gas temperature and the atmospheric optical path length (deduced from the $\mathrm{N}_{2} \mathrm{O}$ amount in each spectrum) are given in Sections 2 and 3. Note the co-variations of most gas species and temperature, anticorrelated with changes in the atmospheric optical path length, which track temporal variations in the thickness and density of the volcanic gas layer viewed by our spectrometer.

Figure 5a-c - Temporal variations of volcanic gas ratios during Benbow lava lake degassing: (a) $\mathrm{SO}_{2} / \mathrm{HF}, \mathrm{HCl} / \mathrm{HF}, \mathrm{SO}_{2} / \mathrm{HCl}$ and gas temperature; $\mathrm{SO}_{2} / \mathrm{HCl}, \mathrm{SO}_{2} / \mathrm{HF}, \mathrm{CO}_{2} / \mathrm{HCl}$ and $\mathrm{CO}_{2} / \mathrm{SO}_{2}$ ratios during (b) our first measuring sequence and during (c) an enlarged window of our second sequence.

In Figure 5a ratios are displayed on logarithmic scale to render $\mathrm{HCl} / \mathrm{HF}$ oscillations more readable. In Figure $5 \mathrm{~b}$ data time series are fitted with a moving average of $15 \mathrm{sec}$ period ( 3 consecutive spectra). Framed time windows in Figures $5 \mathrm{~b}$ and $5 \mathrm{c}$ highlight the discrete $\mathrm{CO}_{2}$ degassing events (high $\mathrm{CO}_{2} / \mathrm{HCl}$ and $\mathrm{CO}_{2} / \mathrm{SO}_{2}$ at otherwise steady $\mathrm{S} / \mathrm{Cl} / \mathrm{F}$ ratios) corresponding to the bursting of meter-sized gas bubbles at the surface of the lava lake, which we attribute to the intermittent ascent and bursting of deeper-derived $\mathrm{CO}_{2}$-rich large bubble or slugs in Benbow volcanic conduit (Section 4.2). See text for discussion.

Figure 6 - Morlet wavelet periodograms of the volcanic gas temperature and five volcanic gas ratios $\left(\mathrm{HCl} / \mathrm{HF}, \mathrm{SO}_{2} / \mathrm{HF}, \mathrm{SO}_{2} / \mathrm{HCl}, \mathrm{CO}_{2} / \mathrm{HCl}\right.$ and $\left.\mathrm{CO}_{2} / \mathrm{SO}_{2}\right)$ over a 2885 sec sampling time interval.

Colour scale shows wavelet power normalised by variance. Black contours mark $95 \%$ confidence from the significance tests (Grinsted et al., 2004). Areas outside the cone of influence correspond to the edge effects from the wavelet (see section 2 for details). Two main degassing modulations appear : (i) recurrent short-period oscillations of $\mathrm{T}$ and most gas ratios in the band 8-32 sec, sometimes extending up to $64 \mathrm{sec}$, especially well defined for $\mathrm{HCl} / \mathrm{HF}$ and $\mathrm{SO}_{2} / \mathrm{HF}$ ratios; and (ii) a continuous long period modulation of all parameters at around $500-\mathrm{sec}(\sim 8 \mathrm{~min})$, especially well defined by 
$\mathrm{SO}_{2} / \mathrm{HF}$ and $\mathrm{SO}_{2} / \mathrm{HCl}$ ratios. Results are discussed in section 4.2.

Figure 7 - Power spectra of wavelet coherence for two pairs of gas ratios: (a) $\mathrm{SO}_{2} / \mathrm{HF}-\mathrm{HCl} / \mathrm{HF}$ and (b) $\mathrm{CO}_{2} / \mathrm{SO}_{2}-\mathrm{HCl} / \mathrm{HF}$.

Colour scale defines the degree of coherence ( 1 for full correlation) and black lines delineate areas within $95 \%$ confidence level from Monte Carlo simulations. Arrows indicate the phase behaviour of the gas ratios: in phase (pointing right), out of phase (pointing left); first ratio leading (down), second ratio leading (up). A highly coherent behaviour is verified for $\mathrm{SO}_{2} / \mathrm{HF}$ and $\mathrm{HCl} / \mathrm{HF}$ at all times (except in the 250-750 sec interval) and at all periods (though more pronounced in the bands 32-64 and 256$512 \mathrm{sec}$ ). Instead, poor coherence exists between $\mathrm{CO}_{2} / \mathrm{SO}_{2}$ and $\mathrm{HCl} / \mathrm{HF}$, except at around $500 \mathrm{sec}$ periodicity and by intermittence in the band $8-64 \mathrm{sec}$, and the two ratios are clearly shifted in phase owing to a prevalent distinct behaviour of $\mathrm{CO}_{2} / \mathrm{SO}_{2}$. See text for discussion.

Figure 8 - Pressure-related compositional evolution of the magmatic gas phase during closedsystem decompression of Ambrym arc basalt.

The magmatic gas phase evolution was computed from the $\mathrm{K}_{2} \mathrm{O}$-normalised volatile content of olivinehosted melt inclusions in Ambrym's basalt (Allard et al., 2015), representative of the bulk basalt, and using VolatileCalc (Newman and Lowenstern, 2002) for the P-related degassing of $\mathrm{H}_{2} \mathrm{O}$ and $\mathrm{CO}_{2}$ at $1400^{\circ} \mathrm{K}$ from $220 \mathrm{MPa}$ to the surface. $\mathrm{K}_{2} \mathrm{O}$ varies from $1.85 \mathrm{wt} \%$ in the deepest, most primitive and volatile-richest inclusions $\left(\sim 1.2 \mathrm{wt} \% \mathrm{H}_{2} \mathrm{O}\right.$ and $\left.0.1 \mathrm{wt} \% \mathrm{CO}_{2}\right)$ to $2.10-2.14 \mathrm{wt} \%$ in the matrix glass of Benbow erupted products, implying a slight magma differentiation upon ascent (Allard et al., 2015). Illustrated are evolutions of the total gas volume fraction $(\alpha)$, of the molar percentages of $\mathrm{H}_{2} \mathrm{O}$ and $\mathrm{CO}_{2}$ and of the molar $\mathrm{S} / \mathrm{Cl}$ ratio in the magmatic gas phase. The cumulated exsolved amount of each volatile at every pressure step was computed by difference with respect to its initial dissolved content in the most primitive inclusions. A bulk magma degassing process well reproduces the average composition of Benbow volcanic gas. Note however the prominent degassing of both $\mathrm{H}_{2} \mathrm{O}\left(\mathrm{H}_{2} \mathrm{O} / \mathrm{CO}_{2}\right.$ increase) and $\mathrm{Cl}$ (sharp drop of $\mathrm{S} / \mathrm{Cl}$ ratio) in the low-pressure range from 25 to $<10 \mathrm{MPa}$, resulting in 
a marked increase of the total gas volume fraction and, hence, basalt vesicularity. See discussion in section 4.2 . 
Table 1 - Molar composition of Ambrym's basaltic gas from Benbow lava lake in October 2008 and October 2007, compared with volcanic gases from other basaltic arc volcanoes and from lava lakes active in different geodynamic contexts.

\begin{tabular}{|c|c|c|c|c|c|c|c|c|c|c|c|c|c|c|c|}
\hline Volcano & $\begin{array}{c}\text { Measuring } \\
\text { time }\end{array}$ & $\begin{array}{c}\text { Geodynamic } \\
\text { setting }\end{array}$ & $\begin{array}{c}\text { Magma } \\
\text { type }\end{array}$ & $\begin{array}{c}\mathrm{H}_{2} \mathrm{O} \\
\mathrm{mol} \mathrm{\%}\end{array}$ & $\begin{array}{c}\mathrm{CO}_{2} \\
\mathrm{~mol} \%\end{array}$ & $\begin{array}{c}\mathrm{SO}_{2} \\
\mathrm{~mol} \%\end{array}$ & $\begin{array}{c}\mathrm{HCl} \\
\mathrm{mol} \%\end{array}$ & $\begin{array}{c}\mathrm{HF} \\
\mathrm{mol} \%\end{array}$ & $\begin{array}{c}\mathrm{CO} \\
\mathrm{mol} \mathrm{\%}\end{array}$ & $\mathrm{H}_{2} \mathrm{O} / \mathrm{CO}_{2}$ & $\mathrm{CO}_{2} / \mathrm{S}$ & $\mathrm{Cl} / \mathrm{S}$ & F/S & Method & Ref. \\
\hline Benbow, Vanuatu & 2008 & Arc & basalt & 96.2 & 2.2 & 1.1 & 0.35 & 0.19 & 0.003 & 44 & 2.0 & 0.32 & 0.17 & FTIR & 1 \\
\hline Ambrym*, Vanuatu & 2007 & Arc & basalt & 95.0 & 2.1 & 2.1 & 0.49 & 0.21 & nd & 45 & 1.0 & 0.23 & 0.10 & in situ & 2 \\
\hline Masaya, Nicaragua & 1998-1999 & Arc & basalt & 94.2 & 3.3 & 1.4 & 0.86 & 0.19 & $\mathrm{bd}$ & 29 & 2.4 & 0.61 & 0.14 & FTIR & 3 \\
\hline Villarica, Chile & 2009 & Arc & bas. andesite & 90.5 & 5.7 & 2.6 & 0.90 & 0.30 & nd & 16 & 2.2 & 0.35 & 0.12 & FTIR & 4 \\
\hline Villarica, Chile & 2004 & Arc & bas. andesite & 95.0 & 2.0 & 2.1 & 0.63 & 0.23 & nd & 48 & 1.0 & 0.30 & 0.11 & in situ & 5 \\
\hline Miyakejima, Japan & $2000 ?$ & Arc & basalt & 94.9 & 2.0 & 2.7 & 0.24 & nd & nd & 47 & 0.7 & 0.09 & & in situ & 6 \\
\hline Stromboli, Italy & 2006 & Arc & K-rich-basalt & 82.9 & 13.6 & 1.7 & 1.7 & $\mathrm{bd}$ & 0.03 & 6.1 & 8.0 & 1.00 & & FTIR & 7 \\
\hline Etna, Italy & 2000 & Cont. Margin & trachybasalt & 92.0 & 7.3 & 1.0 & 0.10 & 0.07 & 0.004 & 12.6 & 7.3 & 0.10 & 0.07 & FTIR & 8 \\
\hline Erta Ale, Afar & 1974 & Rift & basalt & 76.5 & 11.0 & 8.1 & 0.41 & nd & 0.54 & 7.0 & 1.4 & 0.05 & & in situ & 9 \\
\hline Erta Ale, Afar & 2005 & Rift & basalt & 93.6 & 3.7 & 2.5 & 0.19 & 0.04 & 0.06 & 26 & 1.5 & 0.08 & 0.02 & FTIR & 10 \\
\hline Kilauea, Hawaii & 2004-05 & Hot spot & basalt & 81.8 & 6.4 & 10.7 & 1.1 & 0.45 & 0.05 & 13 & 0.6 & 0.10 & 0.04 & FTIR & 11 \\
\hline Kilauea, Hawaii & 1940 & Hot spot & basalt & 59.9 & 32.2 & 7.8 & 0.05 & nd & 0.73 & 1.9 & 4.1 & 0.01 & & in situ & 12 \\
\hline Erebus, Antarctica & 2004 & Cont. Rift & phonolite & 57.9 & 36.4 & 1.4 & 0.69 & 1.27 & 2.3 & 1.6 & 26 & 0.49 & 0.91 & FTIR & 13 \\
\hline Nyiragongo, EAR & $2005-2007$ & Cont. Rift & nephelinite & 70.0 & 24.0 & 4.6 & 0.26 & 0.11 & 0.87 & 2.9 & 5.2 & 0.06 & 0.02 & FTIR & 14 \\
\hline
\end{tabular}

Data sources: (1) This work; (2) Allard et al., 2015; (3) Burton et al., 2000; (4) Sawyer et al., 2011; (5) Shinohara and Witter, 2005; (6) Shinohara et al., 2003; (7) Burton et al., 2007a; (8) Allard et al., 2005; (9) Giggenbach and Le Guern, 1974; (10) Sawyer et al., 2008b; (11) Edmonds and Gerlach, 2007; (12) Gerlach and Graeber, 1985; (13) Oppenheimer and Kyle, 2008; (14) Sawyer et al., 2008a. EAR: East African Rift.

* Mean composition of bulk Ambrym gas emissions from both Benbow and Marum craters in October 2007.

In situ = standard gas sampling/analysis methods. nd: not determined; bd: below detection.

Table 2 - Gas emission rates from Benbow crater in 2008 and Ambrym in 2007, compared to gas emissions rates from other active lava lakes worldwide.

\begin{tabular}{lccccccccc}
\hline Volcano & $\begin{array}{c}\text { Measuring } \\
\text { time }\end{array}$ & $\begin{array}{c}\mathrm{H}_{2} \mathrm{O} \\
\mathrm{Mg} \mathrm{d}^{-1}\end{array}$ & $\begin{array}{c}\mathrm{CO}_{2} \\
\mathrm{Mg} \mathrm{d}^{-1}\end{array}$ & $\begin{array}{c}\mathrm{SO}_{2} \\
\mathrm{Mg} \mathrm{d}^{-1}\end{array}$ & $\begin{array}{c}\mathrm{HCl} \\
\mathrm{Mg} \mathrm{d}^{-1}\end{array}$ & $\begin{array}{c}\mathrm{HF} \\
\mathrm{Mg} \mathrm{d}^{-1}\end{array}$ & $\begin{array}{c}\mathrm{CO} \\
\mathrm{Mg} \mathrm{d}^{-1}\end{array}$ & $\begin{array}{c}\text { Total Gas } \\
\mathrm{Mg} \mathrm{d}^{-1}\end{array}$ & $\begin{array}{c}\text { Ref. } \\
\text { Benbow, Vanuatu }\end{array}$ \\
2008 & $1.6 \times 10^{5}$ & $9 \times 10^{3}$ & 6500 & 1200 & 350 & 8.0 & $2.1 \times 10^{5}$ & 1 \\
Ambrym, Vanuatu & 2007 & $1.1 \times 10^{5}$ & $1.4 \times 10^{4}$ & 7800 & 1100 & 240 & $\mathrm{nd}$ & $1.3 \times 10^{5}$ & 2 \\
Masaya, Nicaragua & $1998-1999$ & $3.5 \times 10^{4}$ & 2900 & 1800 & 640 & 78 & $\mathrm{nd}$ & $4.0 \times 10^{4}$ & 3 \\
Villarrica, Chile & 2009 & 3100 & 480 & 315 & 60 & 11 & $\mathrm{nd}$ & $4.0 \times 10^{3}$ & 4 \\
Erta 'Ale, Afar & 2005 & 630 & 60 & 60 & 2.6 & 0.4 & 0.7 & $7.5 \times 10^{2}$ & 5 \\
Kilauea, Hawaii & 2009 & 240 & 80 & 900 & 23 & 10 & $\mathrm{nd}$ & $1.3 \times 10^{3}$ & 6 \\
Erebus, Antarctica & 2004 & 860 & 1330 & 75 & 21 & 21 & 54 & $2.4 \times 10^{3}$ & 7 \\
Nyiragongo, EAR & 2005 & $1.5 \times 10^{5}$ & $1.2 \times 10^{4}$ & 3300 & 105 & 26 & 285 & $2.7 \times 10^{5}$ & 8
\end{tabular}

Data sources: (1) This work; (2) Allard et al., 2015, bulk Ambrym emissions; (3) Burton et al., 2000; (4) Sawyer et al., 2011; (5) Sawyer et al., 2008b; (6) Edmonds et al., 2013; (7) Oppenheimer and Kyle, 2008; (8) Sawyer et al., 2008a. 
Figure 1

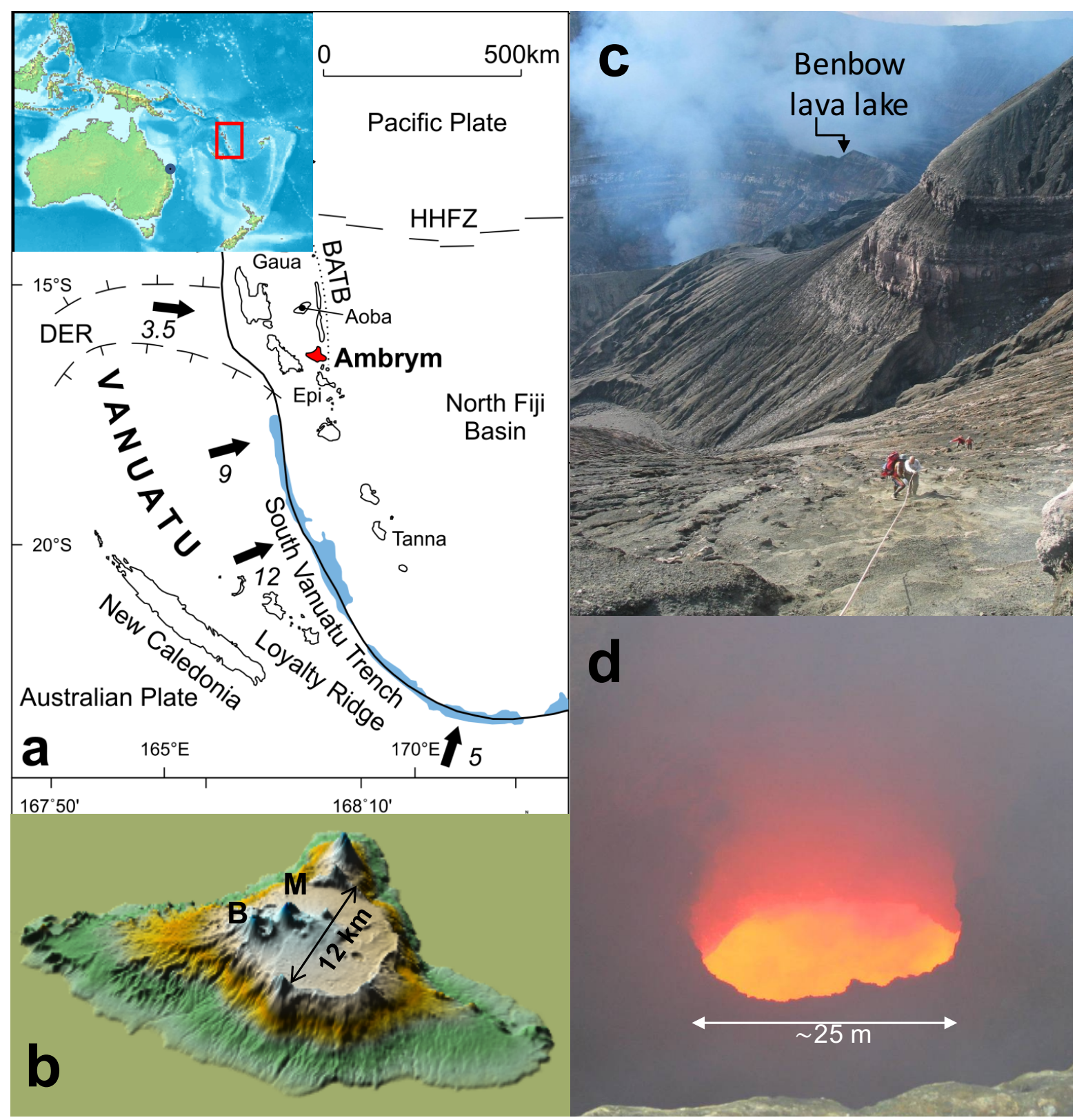


Figure 2

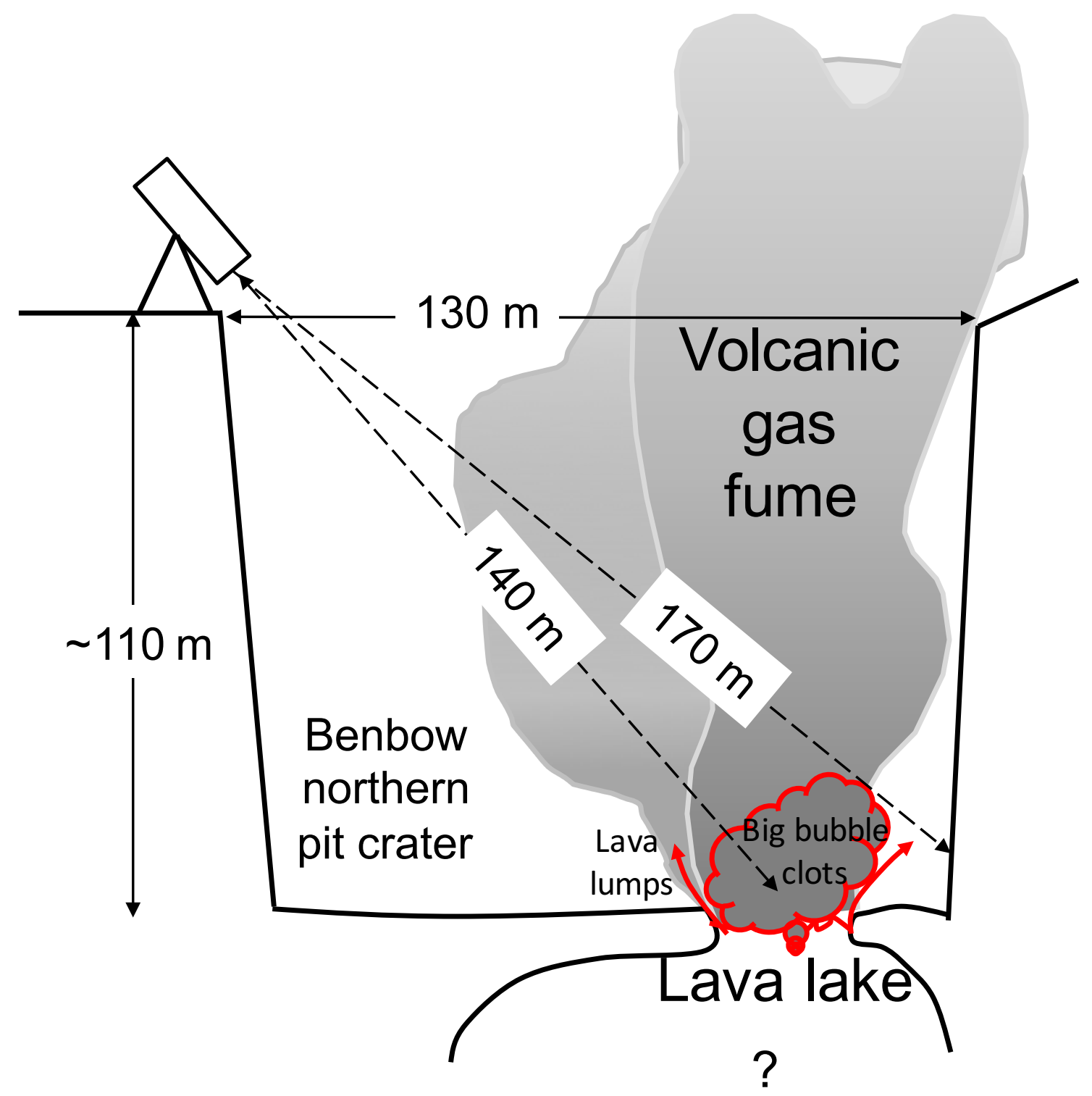


Figure 3 a-c
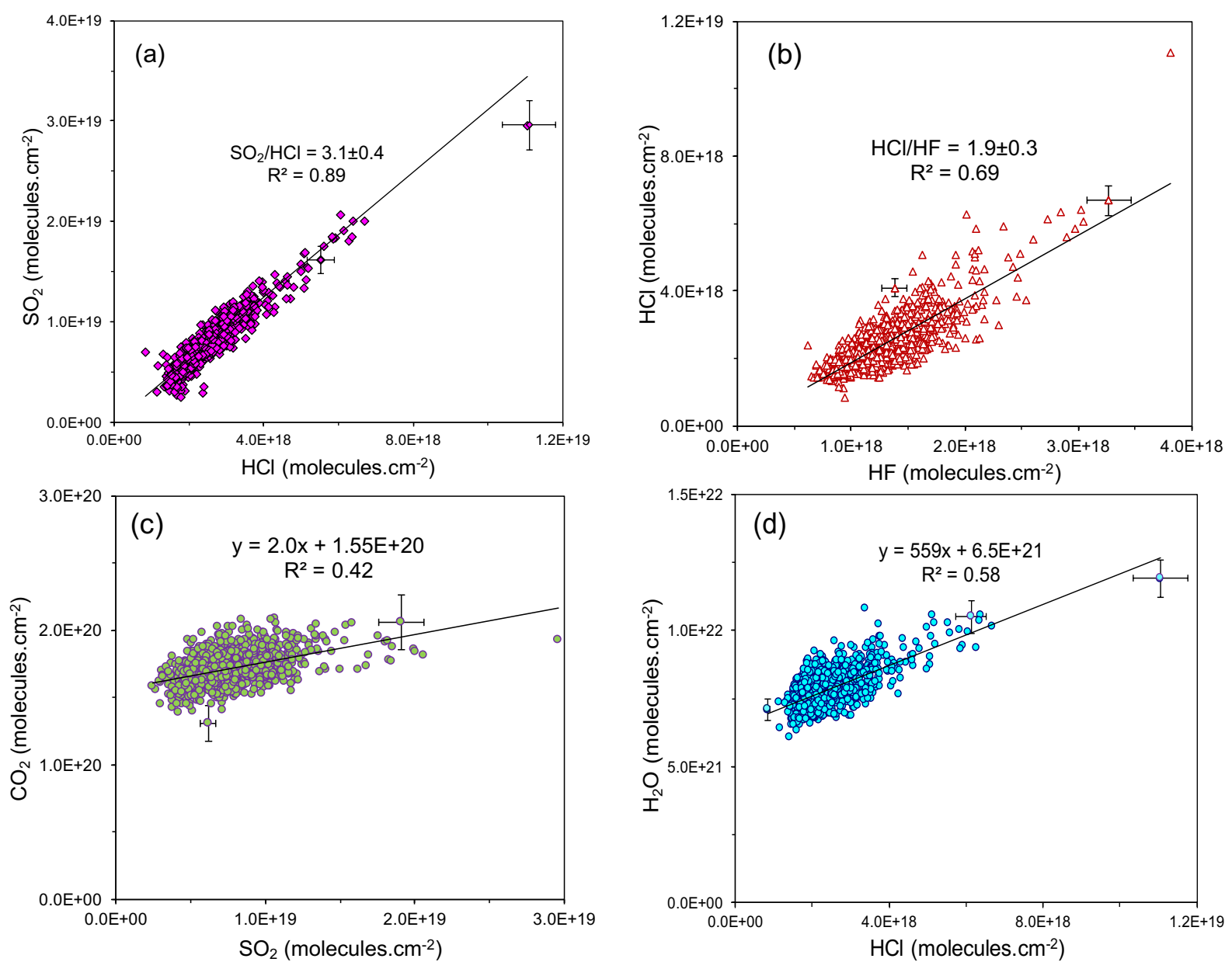
Figure 4 - Time series of the volcanic gas path amounts, the volcanic gas temperature and the atmospheric optical path length for each spectrum during the 1.6-hour interval of OP-FTIR measurement of Benbow lava lake degassing in October 2008.

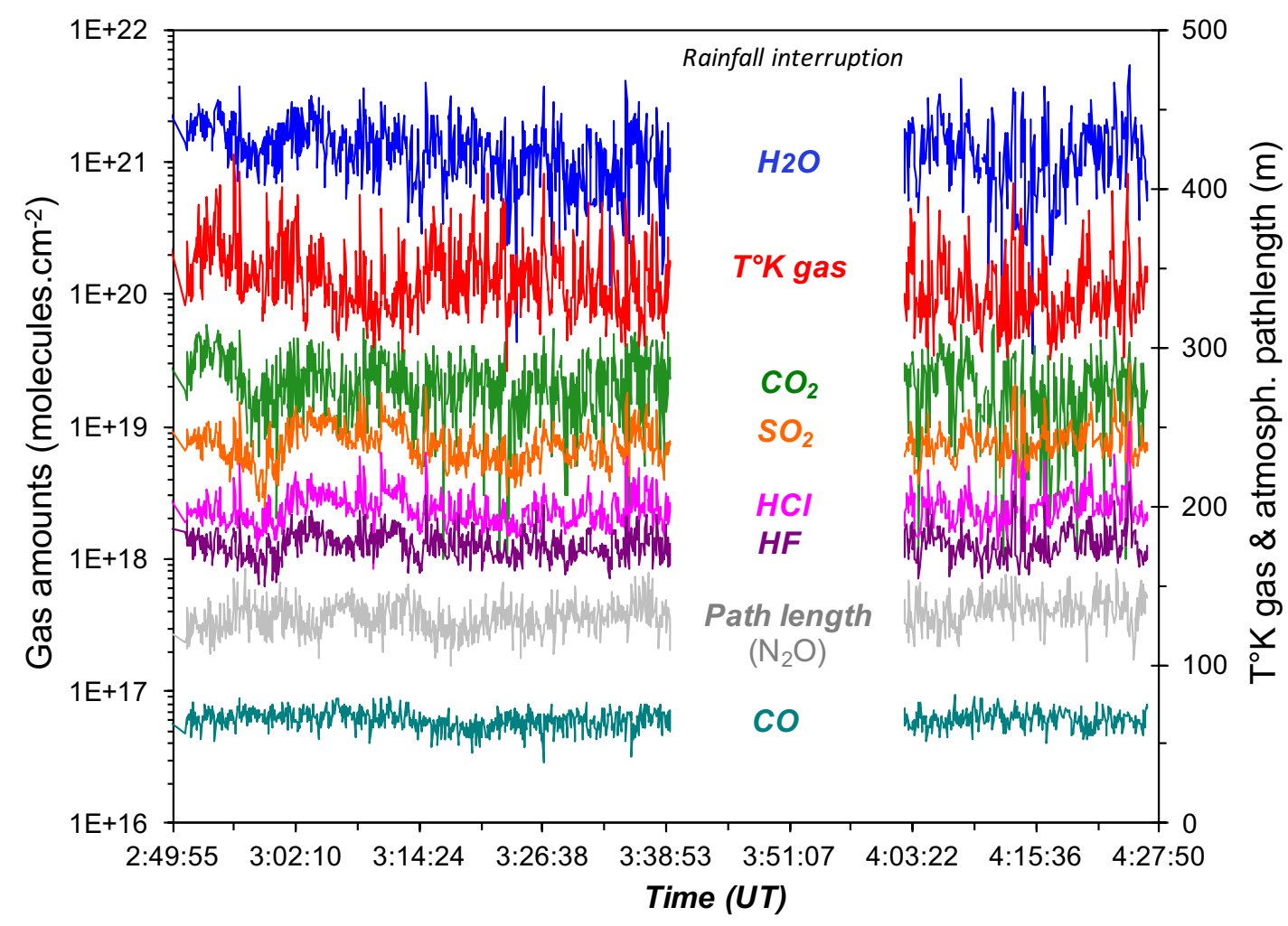


Figure 5a

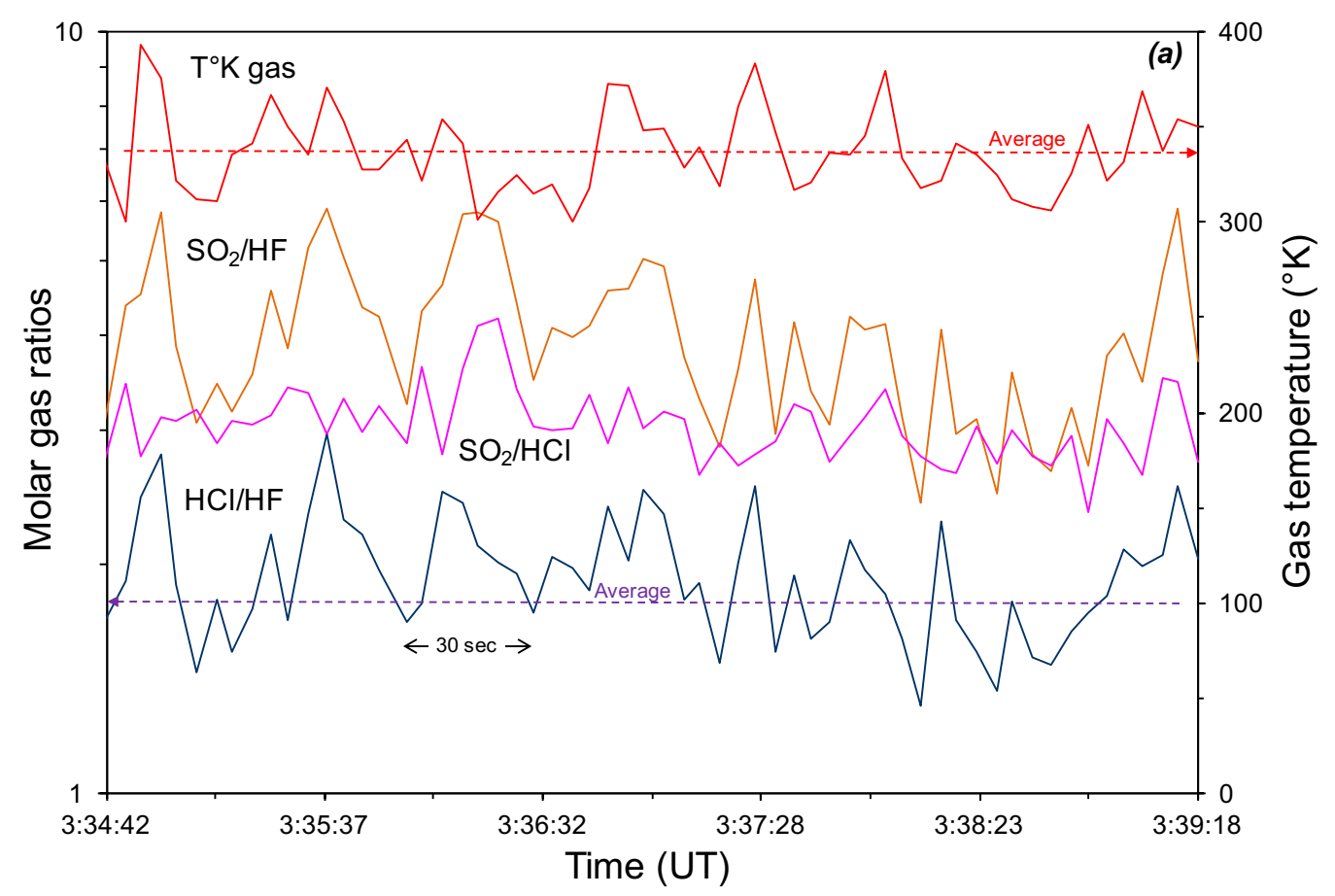

Figure 5b

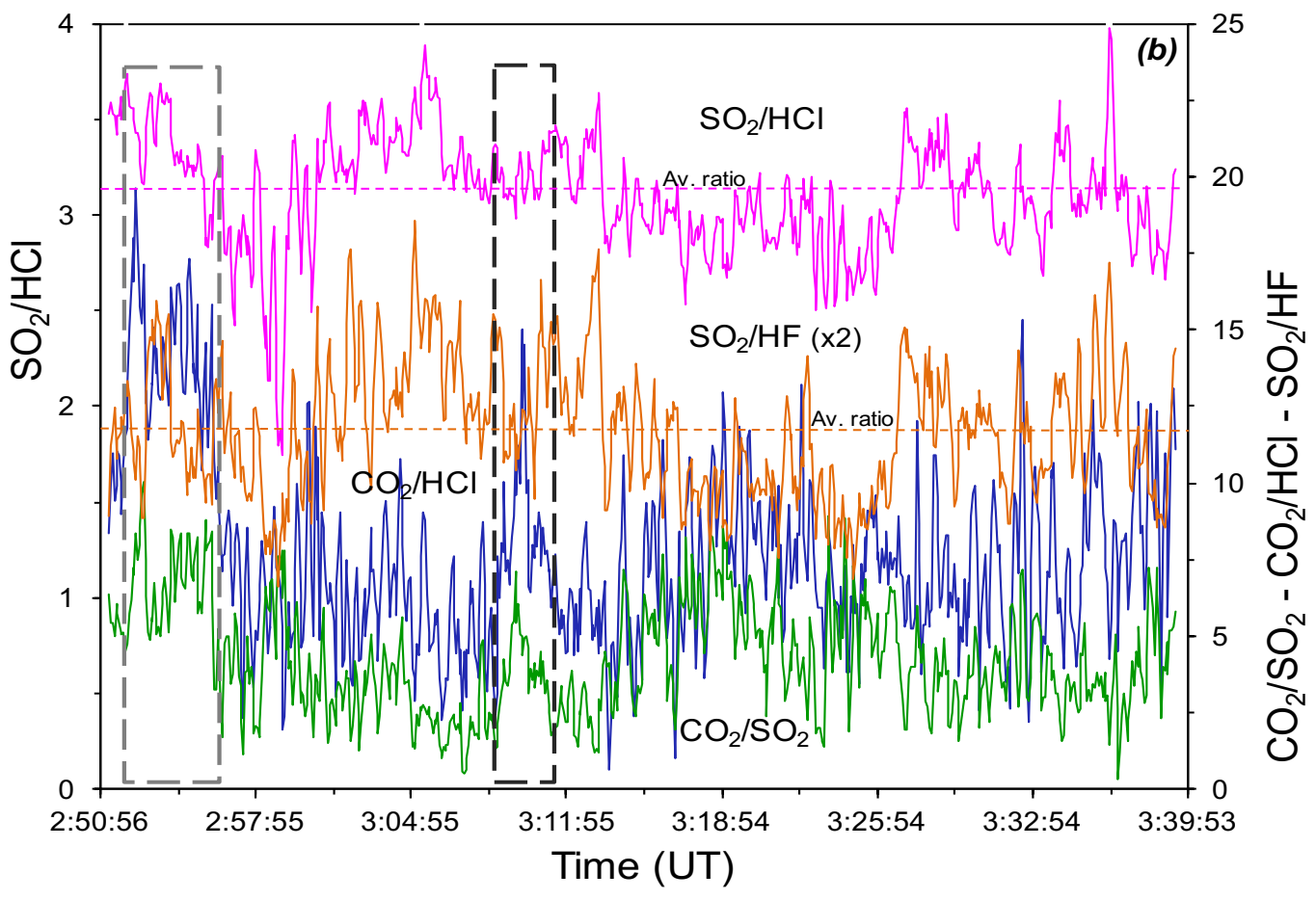


Figure 5c

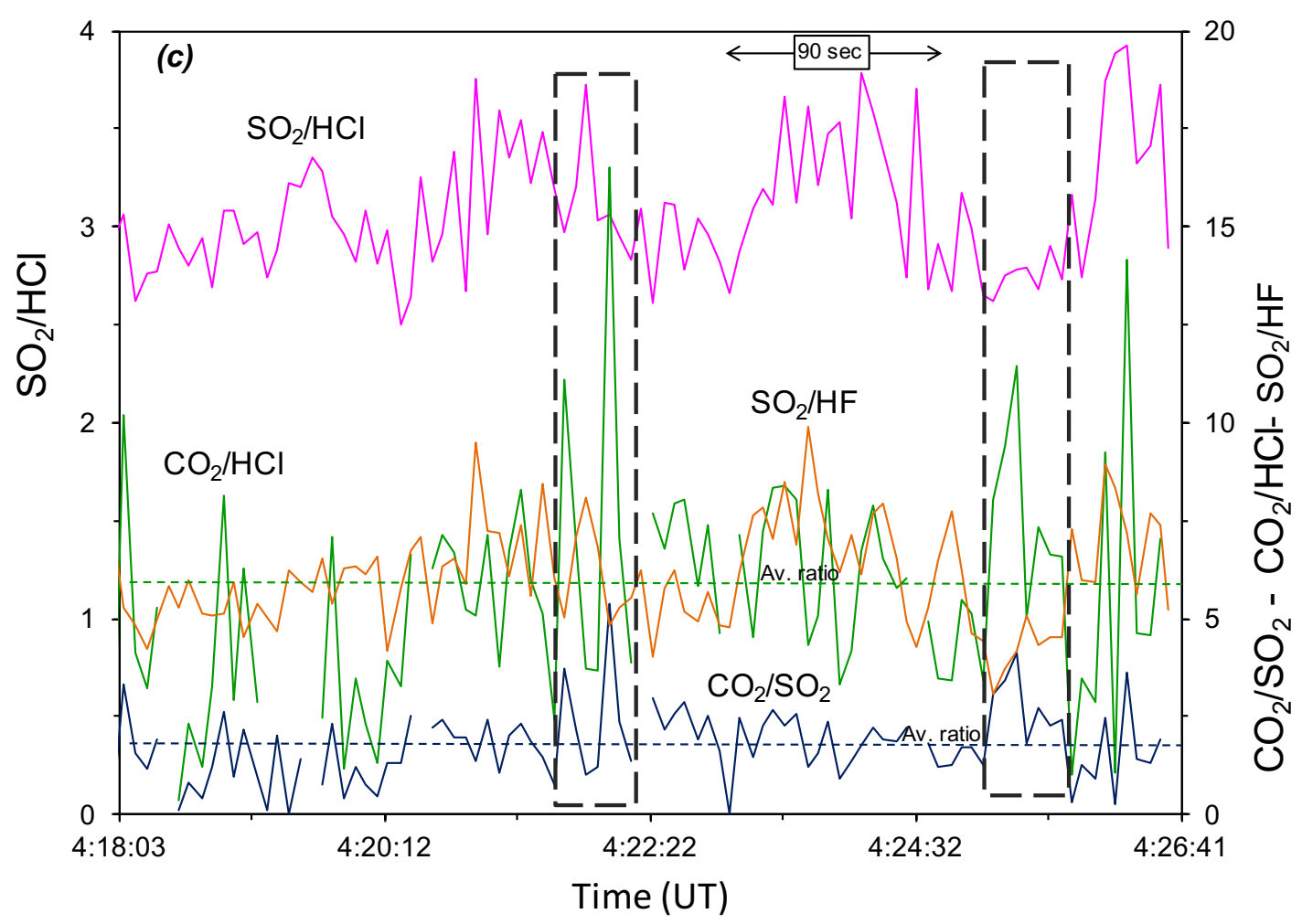


Figure 6
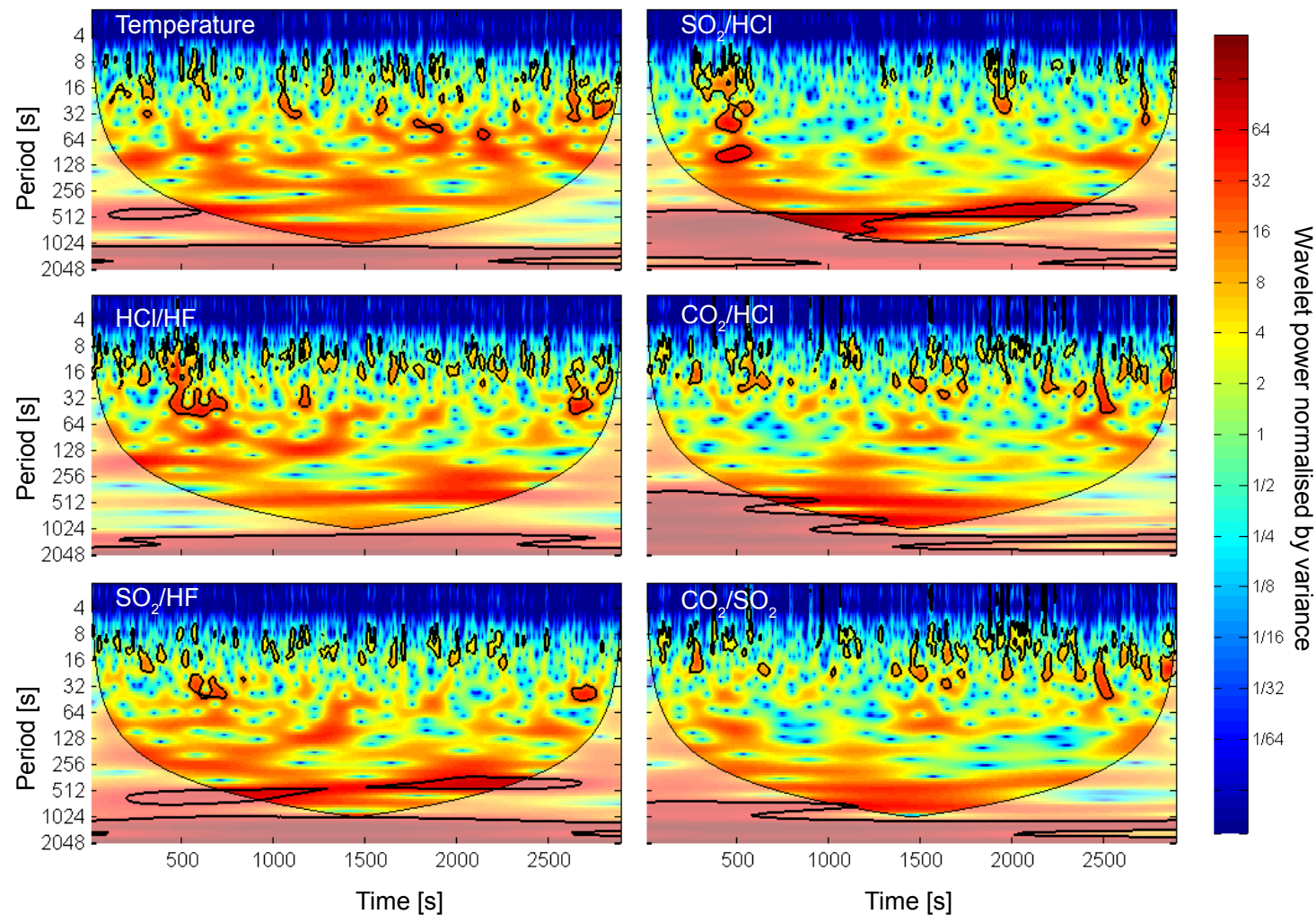
Figure 7

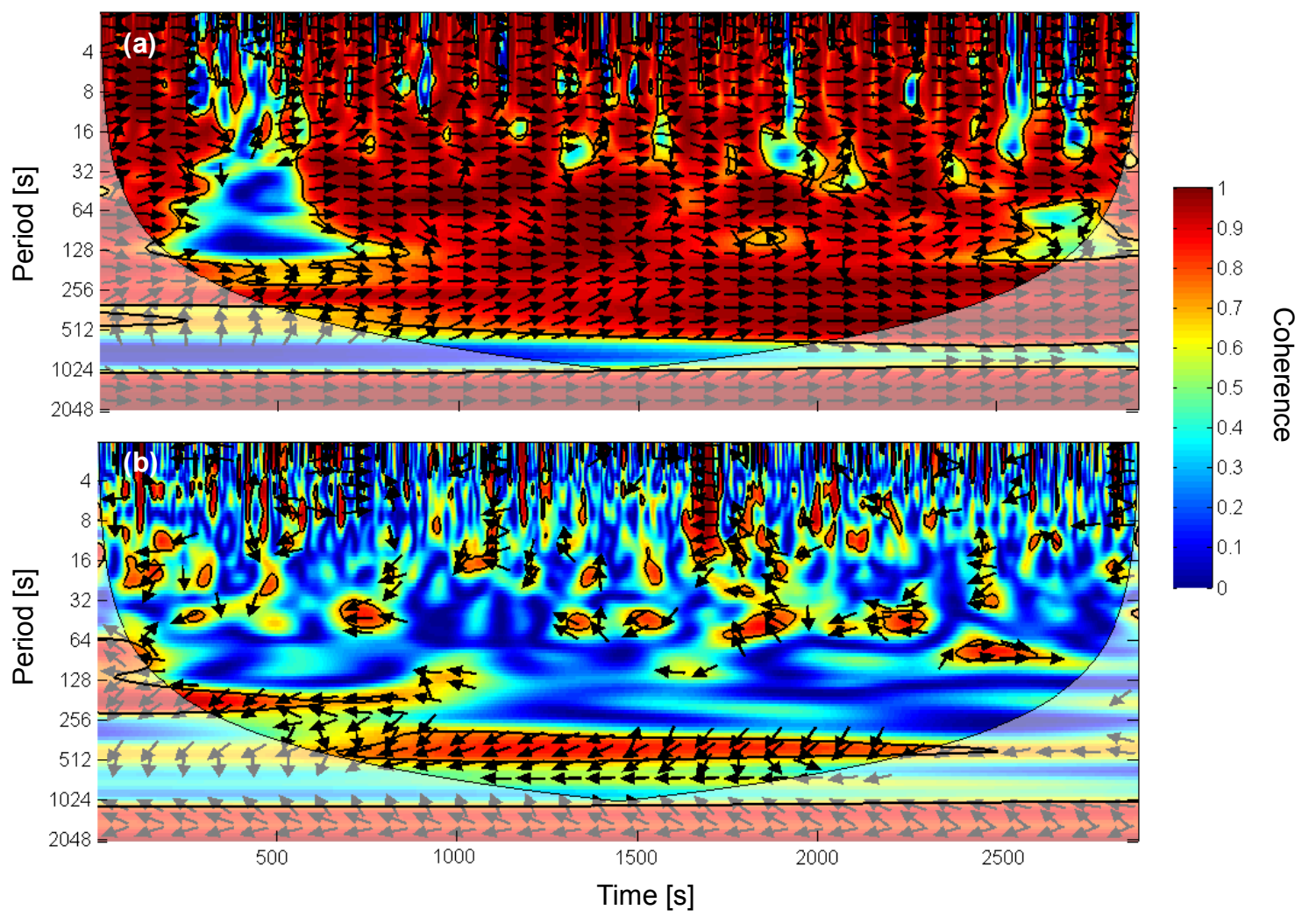


Figure 8

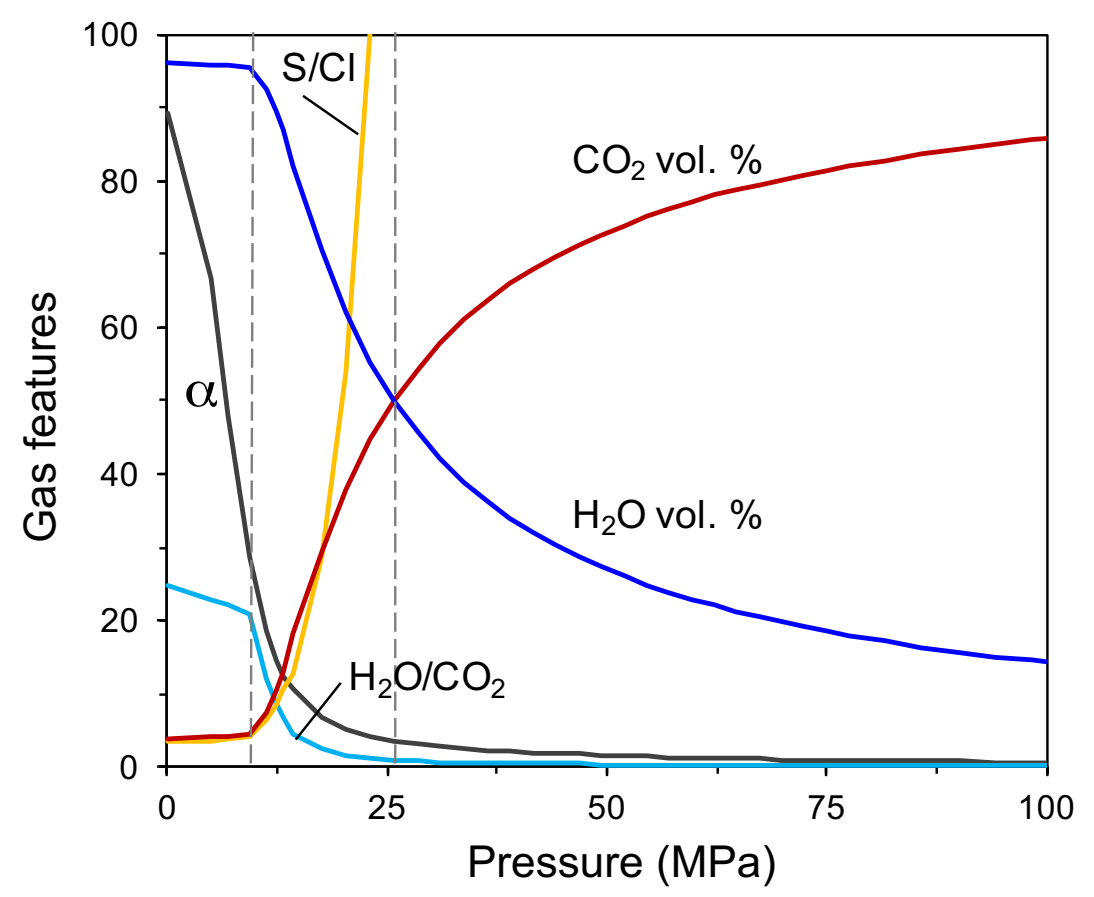

